\title{
Racism In American Courts: Cause For Black Disruption Or Despair?
}

\author{
Derrick A. Bell, Jr.*
}

Beat and cuff the slave, keep him hungry and spiritless, and he will follow the chain of his master like a dog, but feed and clothe him well, work him moderately and surround him with physical comfort, and dreams of freedom will intrude. . . . You may hurl a man so low beneath the level of his kind, that he loses all just ideas of his natural position, but elevate him a little, and the clear conception of rights rises to life and power, and leads him onward.

Frederick Douglass ${ }^{1}$

The insidious destruction of the human spirit is the essence of both slavery and the worst aspects of contemporary white racism. ${ }^{2}$ Perhaps unconsciously, those who have major authority in the legal process tend to underplay the seriousness of racism in the judicial system, acknowledging the need for more progress, while extolling the elimination of overt segregation in the courts. These attitudes show

* Professor of Law, Harvard Law School. A.B., Duquesne University, 1952; L.L.B. University of Pittsburgh, 1957.

This Article is based on a paper prepared for the Special Committee on Courtroom Conduct of the Association of the Bar of the City of New York. I wish to acknowledge the many hours of research performed by Robert Graham, J.D. Harvard, 1972. 1962).

1. F. Dodglass, Life and Tmes of Frederick Douglass 150 (Collier ed.

2. The United States Commission on Civil Rights has defined racism as: "any attitude, action, or institutional structure which subordinates a person or group because of his or their color." A. Downs, RACISM IN AMERICA AND How to CoMBaT IT, 5-6 (U.S. Comm'n on Civil Rights, 1970). In defining this highly provocative term, Mr. Downs distinguishes between: overt racism, "the use of color per se (or other visible characteristics related to color) as a subordinating factor," and institutional subordination, "placing or keeping persons in a position or status of inferiority by means of attitudes, actions, or institutional structures which do not use color itself as the subordinating mechanisin, but instead use other mechanisms indirectly related to color."

Implicit in any definition of racism is the assumption that the majority group has the political and economic dominance necessary to translate its racial biases and prejudices into racial discrimination. See LeMelle, Forward to R. BURKEY, Racial DisCRimination and Public Policy In the United States at x (1971). While racist pohcies facilitate exploitation of the minority group, their crucial impact comes from the demial by the majority group of the minority's basic humanity, and over time, results in the majority's absolute inability (often unconscious) to perceive members of the minority as humans no different from themselves. Unhappily, this notion has a built-in potential for self-fulfillment. As Frederick Douglass warned, "You may hurl a man so low beneath the level of his kind, that he loses all just ideas of his natural position." 
little understanding of the continuing impact of racial bias on black victims of judicial injustice. Typically, these individuals express either consternation that soine black defendants, in the face of progress that has been made, should resort to courtroom disruption, or concern that this disorderly behavior may be a natural consequence of the disproportionate involvement of blacks in reported crimes. Whatever the reaction, however, the conclusion generally reached is that, regardless of cause, courtroom outbursts must be dealt with firmly.

This Article contends that with few exceptions, black defendants in criminal cases have not engaged in disruptive behavior, not because they lack provocation, but because nothing in their personal experience, and little in the history of the black man in Amcrica, providcs them any hope for justice. As Frederick Douglass's statement makes clear, it is frustration of expectations of justice that motivated revolts against slavery. Similarly, protests in and outside the courtroom result only from thwarted expectations. But most black defendants in American courts do not expect equal justice, and even black lawyers are seldom moved either by disappointinent or outrage to protest violently a courtroom procedure or decision that, no matter how unfair, was at least predictable, given the realities of race in America.

In hight of the small number of courtrooin disruptions that have actually occurred, it may be that the depth of public concern reflects an unconscious guilt over society's treatment of blacks; ${ }^{3}$ overreaction to courtroom disruption might be thus explained as a manifestation of guilt about the treatment of blacks in the criminal justice system and fear that black victims will rebel against the oppressiveness of the courts.

It is at least clear that the mere presence of large numbers of black defendents in the criminal courts ensures that any unfairness, whether based on race or class, will measurably burden blacks: blacks suffer disproportionately more arrests and prosecutions, heavicr sentences, longer probations, and fewer paroles. This phenomenon tends to perpetuate the generally held, but infrequently expressed, view that racial injustice in the courtroom is caused, not by society, but by the criminal propensities of blacks. And it is the realization that society is not even willing to acknowledge this bias of the criminal justice system that leads blacks-lawyers and defendants-to face the judicial system not with thoughts of destruction, but with despair.

3. By analogy, society has traditionally imposed its harshest penalties-legal and extra-legal-on black men charged with sexual attacks on white women. Some psychologists view this reaction as a reflection of white guilt over society's appropriation of the black woman as a sexual object. Cf. A. KARDINER \& L. OvesEY, The Mark of Oppression: Explorations in the Personality of the american NEGRO 45 (1962). 
I.

\section{Perceived Injustice As a Cause for Disruptions}

\section{A. Unexamined Motivation in Illinois $v$. Allen}

It may well be, as critics of law schools suggest, ${ }^{4}$ that the most crippling intellectual weakness of modern lawyers is the ingrained habit of focusing on the legality of results while giving virtually no attention to underlying causes. This phenomenon certainly characterizes most of the concern over courtroom distuption.

For example, the 1969 spectacle in Chicago was the predictable outcome of the charade of law enforcement during the 1968 Democratic Convention in Chicago. But the legal profession's major concern in the wake of that event has been to curb courtroom disruptions on the predictably narrow reasoning that there is simply no justification for conduct that disrupts court proceedings. Hopelessly enshrouding the issue in hyperbolic rhetoric by referring to the courts as "palladiums of liberty" and "citadels of justice," the Supreme Court in Illinois v. Allen ${ }^{5}$ approved severe sanctions against court disrupters, usimg as a vehicle the case of an obviously inentally unbalanced defendant.

Even though Allen was white and politically uninvolved, it is now embarassingly apparent that his case was decided with one eye on the happenings in Chicago and a few other well-publicized trials with political overtones in which the defendants, with more or less provocation from the court, had departed from the traditional standards of courtroom behavior. Although judicial imsensitivity was more subtle in Allen's trial than in the Chicago Seven case, it nevertheless was a contributing cause of Allen's "abusive and disrespectful" behavior. ${ }^{6}$ The record in the case provides numerous examples illustrating this point, but perhaps the clearest instance involves Allen's decision to defend himself. This decision was not one that Allen readily made. It was provoked by several pretrial encounters with the judge that caused Allen to distrust the criminal process and finally to demand the only reliable counsel available-_himself.

The difficulties began with pretrial proceedings before the trial judge. The court was anxious to provide a public defender despite Allen's protest that the public defender was incompetent. ${ }^{7}$ When Allen asked for a lawyer from the Chicago bar, the court was willing to

4. Savoy, Toward a New Politics of Legal Education, 79 YALE L.J. 444 (1970); c.f. J. Frank, CourTs on Trial 225-46 (1963); Nader, Law Schools and Law Firms, 54 MINN. L. REv. 493 (1970).

5. 397 U.S. $337,346-47$ (1970).

6. Illinois v. Allen, 413 F.2d 232, 233 (7th Cir. 1969).

7. Appendix, Illinois v. Allen, at 4. 
oblige, but added, “. . . . if he will not represent you, why if you won't take him, then it is up to you to get a lawyer or attempt to defend yourself."

To this Allen responded, "No, no, no, I am incompetent, I can't defend myself."

The Court then added, "I was going to say that men who defend themselves generally go to the penitentiary."

This minor episode, though seemingly harmless in itself, provided the foundation for later, more vociferous exchanges. Allen did not trust the public defender, and the court did little to ease lis fears. But Allen did not want to defend himself; lie wanted representation by a lawyer, and more than the mimimal proteetion the criminal process gives poor defendants.

A month later, in additional pretrial proceedings before the same judge, Allen's frustrations were heiglitened. The assistant state's attorney asked the court appointed lawyer low much time would be needed to prepare, to which he responded, "Frankly, I haven't even seen but just casually I would tlink . . . ."

At this point, Allen, apparently angered by his lawyer's lack of pretrial preparation and fearful of receiving an inadequate defense, blurted out:

"Wait a minute. Wait a minute right here. We are going to handle them with another, we are going to liave another lawyer on these cliarges. This inan has too mucli work to do. They have six or seven imdictments agamst me. This man can't do this by limself. This man only had fifteen minutes conversation witl me. You are going to give him a continuance. Let him liave a recess and let him get himself together, because he can't handle six cases at once. You are going to give him some more lawyers or let, or let this man have a continuance on the 1957 charge."

The court, insulted and perturbed, retorted that it was more competent than defendant to determine whether more than one lawyer need be provided, but added, "You can rest assured counsel will be given ample time to prepare for the case upon which the State proceeds, and the State will advise him in advance as to what date he expects to proceed."

To this Allen responded, "I am beginning to thimk you miglt need a little sanity test yourself."

8. Id. at 6 .

9. Id. at 7 . 
The court answered, "Well, that may be true."10

Thus assured by the judge, Allen waited until the commencement of trial two months later before he again voiced objection: "I want to be my own lawyer. I don't want him no more."1i

The court warned Allen that it was not going to permit properly chosen lawyers to be rejected without valid reason and insisted that with the court-appointed attorney, Allen would get better results. Allen responded:

"I beheve I'll be a success. Anyway, the only time I've ever seen this lawyer was just now for about two minutes back in the bullpen. I've never seen him before that. I've never seen him before, since you told me last time I was in court to see him and talk to the lawyers, and you told me to talk to him now. This is the first time I've ever seen him and for only two mimutes."12 Although the judge was satisfied that the court-appoimted attorney had diligently prepared to represent Allen, the judge decided to let Allen defend himself, but required the appointed attorney to sit in and supervise.

Allen thus became his own lawyer despite his admission at the first pretrial conference that he was imcompetent and could not defend himself. He had been driven to this position by the subtle workings of the criminal process-the poimted and disapproving remarks of the judge, the lack of opportunity to meet with his own counsel, the attorney's failure to prepare, and Allen's basic distrust of the court. All these factors combined to create such frustration that Allen took what he believed was his only available course-to defend himself. As his own lawyer, Allen could not sit by passively during the trial but instead had to play a leading role in an arena where he had no skill and received from the court little sympathy. It was almost predictable that Allen, a former mental patient who felt that he had been treated unfairly by the court, would drop any pretense of respect and become abusive and disrespectful.

Disruption in the courtroom, like disorder in the streets, must be dealt with firmly when it occurs. But it is unfair and, in the long run, the most dangerous kind of folly to self-righteously impose harsh penalties on the disruptors and ignore the causes of outbursts which are often prompted by flagrant imjustices that need to be remedied, not rationalized. The majority opinion in Allen too easily dismissed the causes and significance of courtroom disruptions by blithely admitting that, "Being manned by humans, the courts are not perfect and are

10. Id.

11. Id. at 8 .

12. Id. at 9. 
bound to make some errors." 13 The Court's overreaction was expressed in the warning: "It would degrade our country and our judicial system to permit our courts to be bullied, insulted, and humiliated and their orderly progress thwarted and obstructed by defendants brouglit before them and charged witl crimes."14 But this rhetoric adds little substance to the debate.

The isolated courtroom outbursts by defendants and attorneys in a few well-publicized trials during the last few years did not, despite dire predictions, becoine the prelude to general revolt in the criminal courts. As illustrated in Allen, disruptive behavior stems from several causes. One cause is the perception by defendants (often with good reason) that their prosecution is politically motivated. A review of the disruptive trials of the last few years or even of notorious political trials in the last few hundred years, ${ }^{15}$ suggests that the real danger to the courts emanates less from obstreperous defendants than from overzealous prosecutors whose actions are inotivated more by political concerns than professional judgment. Rather than finding ways to suppress courtroom disruption, the real problein, as Justice Douglas suggested in his dissent to Allen, may be to define better procedures for conducting political trials or even to find constitutional methods of putting an end to them altogether. ${ }^{16}$

Trial judges have been given ample autlority to quell outbursts by both the Allen decision and new, more strict standards for courtrooin beliavior and sanctions for misconduct suggested by the American College of Trial Lawyers and the American Bar Association. ${ }^{17}$

13. 397 U.S. at 346. Mayberry v. Pennsylvania, 400 U.S. 455 (1971), imposed some limit on the trial judge's power to control disruptions. The Court held that where the defendant has reviled the judge, if the judge does not act the instant the contempt occurs, but delays until the end of the trial, then another judge should preside over the contempt proceeding. The 11 to 22 year sentence for contempt was vacated and remanded. The Court expressed the view that the standards in Allen, decided after the Mayberry trial, provided remedies that would likely prevent the constant repetition of the kind of disruptions experienced in Mayberry. Citing Mayberry, a New York court upheld the summary contempt conviction of a spectator who continued, despite a warning, to raise his arm in a "defiant salute" while others shouted "All power to the people" each time the defendants in a Black Panther crimmal prosecution were brought into the courtroom. Katz v. Murtagh, 28 N.Y.2d 234, 269 N.E.2d 816, 321 N.Y.S.2d 104 (1971).

14. 397 U.S. at 346.

15. Id. at 352 n.2. See also R. Morris, Fair Trial (1967).

16. 397 U.S. at 356.

17. Committee on Disruption of the Judicial Process, American College of Trial Lawyers, Report aNd Recommendations on DisRUption of the JUdclal Process (1970); American Bar Association, Advisory Committee on the Judge's Function, Standards Relatino to the Function of a Trial Judge (preliminary draft, August 1970).

In review of both the ABA and American Trial Lawyer's standards, Professor Geoffrey Hazard points out the rules' shortcomings when applied to the ordinary case 
These rules are sufficient to squelch the unfortunate defendant who, like Allen, is deemed legally sane, but who obviously lacks the emotional control needed for the courtroom. ${ }^{18}$ They will likely also give pause to those who, according to Justice Douglas, ". . . . historically have used [disruptive trial] tactics to incite the extreme right with the calculated design of fostering a regime of repression from which the radicals on the left hope to emerge as the ultimate victor." 19

\section{B. Black Defendants and Disruptive Trials}

It is paradoxical that rules handed down in a case involving disruption by a white defendant were likely intended to control courtroom disruptions by blacks. But the harsher sanctions approved in Allen will not be needed to control black lawyers and their clients despite the larger than life image a bound and gagged Bobby Seale at The Chicago Conspiracy trial cast over the American judicial landscape. ${ }^{20}$

and the inappropriateness of attempting to handle the problem of the political trial "by the threatening mechanisms of legal prescription and penal sanction." Hazard, Review: Securing Courtroom Decorum, 80 YALE L.J. 433, 450 (1970).

The American Bar Association, at its 1972 convention in San Francisco, replaced its 50-year-old Canons of Judicial Ethics. The new code contaims more stringent provisions concerning reporting of extra-judicial income (canon 6), tiglitened restrictions on political activity (canon 7), but says no more concerning judicial demeanor in the courtroom than that the judge should "[b]e patient, dignified, and courteous toward litigants, jurors, witnesses, lawyers, and others who appear before him, and require like conduct by his staff, court officials, and lawyers" (canon 2).

18. Illinois v. Allen, 397 U.S. 337, 352 (1970). (Douglas, J., dissenting).

19. Id. at 356.

20. Seale's sentence of four years for sixteen acts, which, as in Allen, grew out of right to counsel issues, was reversed on the basis of Seale's right to have the contempt cliarges heard by someone other than the trial judge, his right to a jury trial on the contempt charges, and the trial court's failure to interrogate him as to his objection to available counsel. United States v. Seale, 461 F.2d 345 (7th Cir. 1972). But the court devoted several pages to making clear that the trial court's adverse rulings did not justify Seale's contemptuous conduct.

It appears that no more than a dozen cases actually involving serious courtrooin disruptions have reached the appellate courts since Allen was decided. Significantly, several of these cases grew out of disturbances sparked by defendant dissatisfaction with defense counsel. See, e.g., Morris v. State, 249 Ark. 1005, 462 S.W.2d 842 (1971) (black defendant returned to jail for balance of trial after lie carried out threat to "pull a Bobby Seale" after his motions to discliarge his cliosen attomey and provide attorney fees for counsel were denied); Commonwealth v. Snyder, $443 \mathrm{~Pa}$. 433, 275 A.2d 312 (1971) (defendant slammed table, refused to be silent after what he considered an improper presentation by his attorney); State v. Dickerson, 9 N.C. App. 387, 176 S.E.2d 376 (1970) (indigent defendant refused to be seated when his request to discharge court-appointed attorney was denied); State v. Newton, 2 Ore. App. 412, 467 P.2d 978 (1970) (defendant cursed and criticized judge after requests to discharge court-appointed attomey aud requests for an all-black trial jury were denied). In other cases, the nature of the defendant's violent outbreaks posed serious questions as to their emotional stability, if not their sanity. See, e.g., State v. Paul, 83 N.M. 527, 494 P.2d 189 (N.M. Ct. App. 1972) (insanity was an issue where defendant's out- 
Seale's vigorous protests were emulated by some of the defendants in the Black Panther conspiracy trial in New York, and perhaps in a few other places. But these were the exceptional cases, involving unusually militant black activists, generally with radical white attorneys who believed that the prosecutions were part of a scheme of continumg police harrassinent. ${ }^{21}$ For less sensational cases the number of courtrooin disruptions attributable to black defendants or black attorneys, compared to the number of blacks charged with crimes are few. Nimety percent of all convicted criminal defendants waive their trial right in return for a bargained plea with the prosecutor. ${ }^{22}$ Even of those criminal cases that do go to trial, the number mvolving disruptions is

bursts led to his being bound and court's statement that on further outbursts he was to be gagged and shackled); State v. Guy, 82 N.M. 483, 483 P.2d 1323 (N.M. Ct. App. 1971) (stating his refusal to stand trial in that county, defendant insulted court and spectators, cut his wrists with a razor, screamed and lay on the floor).

Courtrooin disruptions based on defendant dissatisfaction with counsel might be reduced if two recent decisions signal a trend. In Drungo v. Superior Court, $26 \mathrm{Cal}$. App. 3d 647, 103 Cal. Rptr. 100 (1st Dist. 1972) the trial court's refusal to appoint the attorney a well-known black militant preferred for his multiple-inurder trial was held to be an abuse of discretion. The court held that when a trial judge rejects a timely request to appoint a lawyer who is ready, willing, and able to assume the defense, he must state reasons for his actions. United States v. Dougherty, 41 U.S.L.W. 2054 (D.C. Cir., June 30,1972 ) involved the appeal of activist clerics convicted of burglary and property destruction during a protest "raid" of a napalm manufacturer's office. The court held that under 28 U.S.C. $\$ 1654$, defendants have a right to represent theinselves. While not reaching the issue of whether this right was guaranteed by the Constitution, the court held that "It is just possible that if allowed to represent themselves, defendants could have more effectively presented their unusual defense." The court held the right could be lost through disruptive activity, but found that the defendants' disruptive behavior at the trial was no bar since it resulted from denial of the right.

21. The confrontations between Black Panthers and police in recent years are well known. Illustrative of the intensity of police "surveillance" of Panther activities is a 1969 Los Angeles study in which 15 college students (black, white, and chicano), all with exemplary driving records, were asked to place "Black Panther" buinper stickers on their cars. The group subsequently received 33 citations for driving violations in 17 days. Heussenstam, Bumper Stickers and the Cops, Trans-ACTION, Feb. 1971 , at $32-33$.

22. See D. Newman, Conviction: The Determination of Guilt or InNocence wITHOUT TRIAL 3-4 (1966). Plea bargaining, whatever its practical benefits to the "guilty" defendant, is usually devastating to the accused who proclaims his innocence. Nonetheless, the Supreme Court deems plea bargaining appropriate, but courtroom outbursts mappropriate regardless of justification. During the same term in which the Court found Allen had waived the right to be present at his trial, it also decided a number of cases which in effect give judicial approval to the plea bargaining process. See Brady v. United States, 397 U.S. 742 (1970); Parker v. North Carolina, 397 U.S. 790 (1970); McMann v. Richardson, 397 U.S. 759 (1970). The Court extended its approval of the bargained plea to include cases where the plea is accompanied by protestations of innocence. North Carolina v. Alford, 400 U.S. 25 (1970). The insensitivity to the problems of waiver and voluntariness indicated in the opinions in these cases indeed causes one to wonder along with Michael Tigar whether the Supreme Court understands what really goes on in the criminal courts. See Tigar, Forward: Waiver of Constitutional Rights: Disquiet in the Citadel, 84 HARv. L. REv. 1, 4 (1970). 
virtually unmeasurable. ${ }^{23}$ This is so even in the face of the widespread perception that blacks are not treated fairly by the courts. ${ }^{24}$

But paradoxically, results of several recent trials of black radicals suggest that when such cases attract national publicity and skillful counsel, militants may stand a far better chance of obtaining a fair trial than the great number of black defendants facing charges less obviously connected with race and politics. ${ }^{25}$ However, it is the exceptional black defendant whose militant reputation or conduct ensures that his prosecution will attract national attention, competent counsel, and a special effort by the system to be fair. Thus, it is premature to assert, as the New York Times did editorially, that the acquittal of the 13 Black Panthers charged with conspiracy to boinb police stations and department stores exposes the Panthers' "noisy and noisome oratory" about the nature of justice in America as a fraud. ${ }^{26}$ Even a brief

23. Inquiries undertaken by the writer with a selection of black trial judges around the country indicated no knowledge of any tendency on the part of black defendants or their attorneys to disrupt courtrooms. The judges indicated that while there are heated exchanges particularly during the trial of a serious felony, and occasionally an intemperate out of court attack on the judge, they had heard of no general difficulties with courtroom decorum involving blacks. Judges interviewed included: Judge Joseph Mitchell of the Supreme Court of Middlesex County, Massachusetts; Judge Jawn Sandifer, Supreme Court, New York; Judge George Crockett, Detroit Recorder's Court.

Preliminary results from 1,600 trial judges who responded to a cross-country survey sponsored by the Association of the Bar for the City of New York turned up only six cases in which contempt citations had been issued against lawyers for courtroom behavior. An independent check by the New York Times of court officials in 13 major cities and interviews with legal authorities around the country also indicated that court disruption is not a serious problem. See N.Y. Times, Aug. 9, 1971, at 1, col. 3.

24. As a black lawyer observed (shortly after Yale President Kingman Brewster questioned whether black radicals such as the Black Panthers could get a fair trial in this country) there is ample reason, "[g]iven the special relationship blacks have had to the law since they were brought to this country," to wonder whether any black man in America can receive a fair trial, if by fair one means free of racial bias. Burns, Can a Black Man Get a Fair Trial in This Country?, N.Y. Times, July 12, 1970, § 6 (magazine), at 5.

25. The acquittal of Angela Davis stands as a dramatic illustration of this phenomenon. Another example occurred in the acquittal of 13 Black Panthers charged with a conspiracy to bomb department stores and police stations and to murder policemen. N.Y. Times, May 14, 1971, at 1, col. 8. Other well-publicized trials of Panthers in Newark, New Haven, Oakland, and Los Angeles have also ended with either acquittals or verdicts generally favorable to the defendants.

Dr. W. E. B. Dubois, in writing of his own political trial in 1951, noted this phenomenon: "We protect and defend sensational cases where Negroes are involved. But the great mass of arrested or accnsed black folk have no defense." W. DuBors, THE AUTOBIOGRAPHY OF W.E.B. DuBOIS 390 (1968).

26. N.Y. Times, May 15,1971 , at 30 , col. 1 . What the Times editorial conveniently forgets, as one reader pointed out, was that

... all that preceded the verdict: the spurious indictınents, the mcredible bail imposed, the inhuman treatinent of the preventively detained defendants who couldn't raise bail; the attempts at intimidation of the defense during the pretrial hearings, the demeaning of defense counsel by the court, the bias of 
survey of recent studies of our judicial system indicates that a fair trial is not a probable outcoine for the black defendant and, indeed, the contrary result is far more likely-particularly for nonmilitant defendants.

II.

\section{STUdies OF CRIME, RACE, AND RACISM}

Most black defendants apparently feel that it is impossible for a black person to get a fair trial in America. In its report on civil disorders, the Kerner Commission found:

The belief is pervasive among ghetto residents that lower courts in our urban communities dispense "assembly lime" justice; that from arrest to sentencing, the poor and uneducated are denied equal justice with the affluent, that procedures sucli as bail and fines have been perverted to perpetuate class inequities. ... Too often the courts have operated to aggravate rather than relieve the tensions that ignite and fire disorders. ${ }^{27}$

These perceptions were strongly reinforced by the performance of the courts in the wake of the serious civil disorders the Commission studied. Institutions established to perform an adjudicatory function were, as Jerome Skolnick put it, ". . . . asked to deal with the outcome of political conflict as if it were only a criminal matter. Under such conditions, they often became and are perceived as an instrument of power rather than of law."28 As the following will show, studies of the criminal justice system and racism in the courts support this perception of justice in America.

\section{A. Racial and Cultural Prejudice}

In a special report on the courts, the Presidents Crime Commission found that racial prejudice, whether operating purposefully in jury selection and sentencing, or unintentionally through inequitable burdens on the poor, seriously threatens the judicial system's capacity to operate fairly. The report cites examples of blatant racial practices that still persist in rural southern courts, but also acknowledges the discrimination in the North, inucle of which is due to the stereotypes and prejudices still harbored by white court employees and white jurors. ${ }^{20}$

court rulings during the trial-hardly the ingredients for a fair trial.

Letter to the Editor, Herbert F. Hecker, Oakhurst, N.J., N.Y. Times, May 25, 1971, at 38 , col. 3. Mr. Hecker's observations are, of course, equally applicable to the Angela Davis and Bobby Seale cases.

27. Report of the National Advisory Comm'N ON Civil Disorders 183 (1968). The Commission found that specific grievances cited by those participating in civil disturbances varied widely, but "police practices" were mentioned most often; "discriminatory administration of justice" was also frequently cited. Id. at 80-81.

28. J. Skolmick, The Politics of Protest 324 (1969).

29. The Prestent's Comm'n on LaW Enforcement and Administration of 
In addition to the known disadvantages suffered by the poor in court, the report discusses the prejudice that can result from social and cultural differences between racial and ethnic groups:

The law and court procedures are not understood by and seem threatening to many defendants, and many defendants are not understood by and seem threatening to the court and its officers. Even such simple matters as dress, speech, and manners may be misinterpreted. Most city prosecutors and judges have middle-class backgrounds and a high degree of education. When they are confronted with a poor, uneducated defendant, they may have difficulty judging how he fits into his own society or culture. They can easily mistake a certain manner of dress or speech, alien or repugnant to them but ordinary enough in the defendant's world, as an index of moral worthlessness. They can mistake ignorance or fear of the law as indifference to it. They can mistake the defendant's resentment against the social evils with which he lives as evidence of criminality. Or conversely, they may be led by neat dress, a polite and cheerful manner, and a show of humility to believe that a dangerous criminal is merely an oppressed and misunderstood man. ${ }^{30}$

Indeed, the President's Crime Commission found conditions in the criminal courts to be so bad that it recommended widespread reform to improve efficiency, reduce delay, and lessen the number of serious miscarriages of justice. ${ }^{31}$ Significantly, the Commission con-

Justice, The Challenge of Crime in a Free Society, A Report (1967) [hereinafter cited as PRESIDENT's CRIME COMMISSION REPORT].

30. The President's Crime Commission, Task Force Report: The Courts 50 (1967). The injustices visited on blacks as a result of the cultural gap between them and law enforcement officials, particularly police, have been extensively documented. Several studies are republished in RACE, CRIME AND JUSTICE 13-55, 139-258 (C. Reasons \& J. Kuykendall eds. 1972), [heremafter cited as RACE, CRIME AND JusTiCE]. See also J. SRolNiCK, JUSTICE WithouT TRIAI (1966).

There is also substantial literature relating criminal behavior to aspects of socioeconomic position, including educational level, employment status, and even length of residence. Several major studies are reviewed in The President's Crime Commission, TASK Force RzPort: Crime aNd ITS IMPACT-AN Assessment 60-75 (1967); and in The Sociology of Crime and Delinquency 417-524 (M. Wolfgang, L. Savitz \& N. Johnston eds. 1962).

Much of the work collected in the cited studies focuses on the problem of race and delinquency. Other inquiries in this area include: Arnold, Race and Ethnicity Relative to Other Factors in Juvenile Court Dispositions, 77 AM. J. Sociology 211 (1971); Gould, Who Defines Delinquency: A Comparison of Self-Reported and Officially-Reported Indices of Delinquency for Three Racial Groups, 16 Social Problems 325 (1969). Several writers have warned of the dangers of using official crime statistics to determine the relationship between race and crime because they are misleading and subject to misinterpretation. See, e.g., T. PetTigrew, A Profile of the Negro AMrRICAN, 136-56 (1964); Geis, Statistics Concerning Race and Crime, in RACE, CRIME, AND JUSTICE, supra, at 61.

31. The Commission quotes Dean Edward Barrett who said of these courts:

Suddenly it becomes clear that for most defendants in the criminal process, there is scant regard for them as individuals. They are numbers on dockets, 
cluded that the best solution to the problems posed by the lower criminal courts would be their outright abolition. ${ }^{32}$

\section{B. Conditions in the Criminal Courts}

Conditions in our criminal courts clearly convey to the black defendant that concern for non-biased justice is mimimal. A 1969 unpublished study by Professor Donald Warren of the University of Michigan School of Social Work, ${ }^{33}$ revealed that criminal cases in Detroit were generally heard in noisy courtrooms where decorum was continually disrupted by police, court personnel, attorneys, witnesses and spectators, ${ }^{34}$ and that inadequate physical facilities contributed to confusion and to a hasty consideration of most cases. ${ }^{35}$

Observers noted that black defendants subjected to these proceedings fared measurably poorer than their white counterparts. ${ }^{36}$ While the judges spent little time on any of the cases (four out of five being concluded im less than 10 minutes and two of five receiving less than three minutes), cases involving black defendants were generally heard in less time than those involving whites. ${ }^{37}$ The Detroit study also found that a significant number of defendants were not advised of their rights. Black defendants were more likely than whites to have received no proper indication of the charge, the right to testify, or the right to call and cross-examine witnesses. ${ }^{38}$

faceless ones to be processed and sent on their way. The gap between the theory and the reality is enormous.

President's Crime Commission Report, supra note 29, at 128. Justice Douglas citcd Dean Barrett's statement in Argerslinger v. Hamlin, 407 U.S. 25, 35 (1972).

32. President's Crime Commission Report, supra note 29, at 129 . Notwithstanding such findings, the Commission has been criticized for its conservative approach to the problem of crime. See J. Douglas. Crime and Justice in American SocietY (1971).

33. D. Warren, Justice in the Recorder's Court of Detrort. AN ANAlYsis of Misdemeanor Cases During the Months of September to December 1969 (1970) [hereinafter cited as DETrort CouRT STUDY].

34. Id. at 4 .

35. Id. at 9 .

36. Id. at 7 .

37. Id. at 8 .

38. Id. at 23. Judge George Crockett, a member of the Detroit Recorder's Court who is familiar with Dr. Warren's study, believes that even though six of 16 judges on the court are now black, conditions have not improved substantially. One problem is the necd to import district court judges from the suburbs to help with the large caseload in the court's misdemeanor division. These judges unconsciously bring with them the racial views of the areas in which they regularly serve, which Judge Crockett feels are, "decidedly inhospitable" to blacks. One result of this lostility is that only 39 percent of the recommendations by the court's new release on own recognizance program were followed by the magistrates, thereby causing overcrowding of jail facilities and considerable animosity in the black community.

The judge has noted a few improvements, however, since the increase in black 
In a 1970 study of the lower criminal courts in Boston, a group of young lawyers discovered shocking practices, particularly in those courts where blacks and other minority groups constitute the inajor portion of the caseload. ${ }^{39}$ The study found, first, that in the urban as opposed to the suburban courts, defendants were not being adequately advised of their right to counsel; $;^{40}$ and second, that bail was set by reference to the charge and the defendant's prior record rather than by reference to factors such as family ties, length of residence in the community, and job and financial resources. This was done even though there was a state law requiring release of the defendant on his own recognizance unless the court affirmatively found such release would not reasonably ensure his appearance at trial. ${ }^{41}$

In the lower Boston courts, according to the study, a series of pressures are exerted against the defendant to discourage him from appealing a guilty verdict, which would entitle him to a trial de novo before a jury in a higher court. A defendant, for example, might be offered a suspended sentence or probation if he waives his appeal right, but an active jail term with a higher bail requirenent if he insists on the right to appeal. ${ }^{42}$ Often a judge will threaten a higher sentence if the defendant appeals. ${ }^{43}$ While the Boston court report focuses on economic disparities and the resultant burdens placed on the poor defendant in the urban courts, the practices the study criticized also

judges. Court personnel and police are displaying more civility, imcluding use of courtesy titles in court proceedings, toward blacks and poor whites. There has been a noticeable increase in black employees in all court departments. And black attorneys are being assigned to more indigency cases.

Judge Crockett reports some concern that the increase in black judges who are elected on a city-wide basis in Detroit, which is 50 percent black, is a factor in the legislature's failure to create six more badly needed judgeships. In addition, he reports that in recent years there has been growing agitation to "inprove" the Wayne County judicial system by abolishing the City Recorder's Court and shifting its caseload to the County Circuit Court thereby requiring black judges to run on a county-wide basis (only 23 percent black) with greatly reduced chances for election. Finally, black lawyers in the state fear that growing support in bar circles to make all judgeships in Michigan appointive rather than elective, is an effort to curtail the present trend toward a racially integrated judiciary. Letter of Feb. 14, 1972 to the author from the Honorable George W. Crockett, Jr., on file with the author.

39. S. BING \& S. ROSENFELd, A REPORT BY THE LAWYER'S COMMITTEE FOR CIVIL RYGHTS UNDER LAW, TO THE GOVERNOR'S COMMTTTEE ON LAW ENFORCEMENT AND THE ADMINISTRATION OF JUSTICE, THE QUALITY OF JUSTICE IN THE LOWER CRTMinal Courts of Metropolitan Boston (1970) [hereinafter cited as Boston Court STUDY].

40. Id. at 51-53.

41. Id. at $62-67$.

42. Id. at $90-92$.

43. Id. at 91. For example, one judge imposes sentences as follows: "You [defense attorney] ask him [defendant] if he wants to pay the inoney back. If not, I'll sentence him to six months on the Island [Deer Island House of Correction]. If he wants to appeal, I'll make it a year." Id. 
resulted in differential treatment by race. Thus, the report found marked racial disparities in bail procedures for defendants who insisted on their right to a trial de novo in the Superior Court. Fifty-two percent of all black defendants who sought trial de novo were defendants committed for failure to make bail; yet, in similar circumstances only 29 percent of the whites were committed. ${ }^{44}$

\section{Disposition of Cases After Judgment}

\section{Probation and Parole}

Racial discrimination exists not only in the conviction process but also in the disposition of cases following judgment. For example, under Florida law, ${ }^{45}$ a judge has the option of withholding adjudication of guilt from a defendant who is placed on probation, thereby enabling him to avoid the stigma associated with the label of convicted felon. A 1969 study of 2,419 felony cases received by the Florida Probation and Parole Commission during an eight month period ${ }^{46}$ revealed that blacks $(41.1 \%)$ are adjudicated guilty more often than whites $(28.3 \%)$, and are placed on probation in less than one-third of the felony cases. ${ }^{47}$ Thus, states the report, "it appears that blacks ac-

44. Id. at 93. The Boston Court study was not an academic exercise. In May 1970, lawyers with the Massachusetts Law Reform Institute (MLRI), many of whom had participated in the study, petitioned the Supreme Judicial Court to exercise its powers of superintendence over the lower courts and promulgate rules to correct abuses uncovered by the study in the arcas of appointed counsel, bail, guilty pleas, continuances, trial procedures, sentences, and appeal. Despite conferences with the court and the submission of additional data to support the findings of the original study, the Supreme Judicial Court announced it would delay action on the petition pending receipt of views from the chief judges of the lower courts involved. One of these, Chief Justice Adlow of the Boston Municipal Court denounced the lawyers who participated in the study, which he called "scurrilous and groundless," expressing the hope that both lawyers would be "consigned to the oblivion from [which they] should not have emerged." Chief Justice Flaschner of the district court system was also critical of the report, but admitted there were problems that needed correction. He promised to do his best for reform, but warned he would not "be stampeded by eager staff personnel on these study groups who must justify their grants." In December 1970, the Supreme Judicial Court issued a press release (not an opinion or order) stating that in view of the replies of Justices Adlow and Flaschner and the continuing discussions between court officials and MLRI lawyers, the court would take no action on the petition. III MLRI, LAW ReForm Report 14-15 (Feb. 1971). Finally, in July 1971, Chief Judge Flaschner promulgated nine "initial" rules of procedure aimed at bail reform and the problems of assigned counsel. Acknowledging the MLRI role, he stated: "While our separate functions preclude a partnership, I do believe we lave developed a healthy working relationship which will contribute to the sound improvement of the administration of criminal justice." IV MLRI, LAW REFORM REPORT 36 (May 1972).

45. Fla. Stat. ANn. $\$ 948.01$ (West Supp. 1972).

46. T. Chiricos \& G. Waldo, Inequality in the Jmposition of a Criminal Label, 1971 (unpubhished study prepared for the Southeastern Correctional and Criminological Research Center, Florida State Univ.).

47. Id. at 6-7. 
cused of a felony are much less likely than whites to be placed on probation, and when placed on probation, they are less likely to avoid being labeled 'convicted felon." "48

The Florida study examined a number of factors that apparently affected the imposition of the felon label, but concluded "that blacks -regardless of prior record, type of offense, age, or any of the other controls-are consistently labeled criminal more often than their white counterparts." 49

The Detroit Criminal Court Study also supports the contention that blacks are less likely to receive probation. The study found that most cases are disposed of with a probation sentence. Again, however, black defendants were found significantly more likely than whites to receive probation rather than a less severe sentence- $51.3 \%$ versus $40.7 \%$. And as the report noted, whites received a fine-" the penalty incurring the least lasting stigma"-rather than some more severe penalty twice as often as blacks. ${ }^{50}$

\section{Sentencing}

More than a decade ago, a sociologist reviewed 3,644 records of white and black prisoners serving sentences in the Texas State Prison for serious crimes (burglary, rape, and murder). He found that the wide range of punishments for a given offense permitted judges to shape their responses to criminal behavior to conform with their individual values, attitudes, and prejudices. ${ }^{51}$ Race was one characteristic that affected the penalty imposed. Negro prisoners found guilty of murder, which is generally an intraracial crime, tended to receive shorter sentences than whites who committed the same offense. ${ }^{52}$ The same pattern was found in rape convictions, which despite the publicity given interracial cases, is generally an intraracial offense. ${ }^{53}$ Negroes who committed burglaries, which is generally perceived as an interracial offense, received longer sentences than whites. ${ }^{54}$

What the study's author calls the "induglent and non-indulgent" patterns of racial sentencing operated undisturbed by the nature of the offender's plea. Although defendants who pleaded guilty could expect lighter sentences, Negro prisoners who pleaded guilty generally

48. Id.

49. Id. at 12 .

50. Detrort CouRt STUDY, supra note 33, at 24.

51. Bullock, Significance of the Racial Factor in the Length of Prison Sentences, 52 J. CRIM. L.C. \& P.S. 411 (1961).

52. Id. at 415-16.

53. Id. at 417 .

54. Id. at 415-16. 
received longer sentences than did whites. ${ }^{55}$ The study also determined that a double standard of moral expectation was applied to blacks. Of defendants convicted for committing interracial offenses, blacks generally received a heavier penalty than whites. But blacks who committed crimes within the confines of the segregated black community received less stringent punishments than their white counterparts. $^{56}$

Even when represented by attorneys blacks may fare no better. The Detroit Criminal Court Study deinonstrated that blacks represented by counsel received jail sentences twice as often as whites. ${ }^{67}$ But evidence that social class as well as racial prejudice affected the sentencing process was suggested. The study revealed that persons who appeared in work clothes were twice as likely to receive a sentence involving loss of freedoin as individuals who appeared in sports clothes or coat and tie. ${ }^{58}$ This greater frequency of jail sentences for blacks may partially be explained by the finding that blacks with counsel were twice as likely to plead guilty than whites with counsel. By contrast, defendants without counsel tended to plead guilty with approximately the same frequency, regardless of race. ${ }^{50}$

Differential imposition of the death penalty is another notorious example of the disparate treatinent accorded black defendants. The President's Crime Commission in recommending abolition of the death penalty, referred to the evidence that death sentences are "disproportionately imposed and carried out on the poor, the Negro, and the members of unpopular groups." ${ }^{\circ}$ Moreover, when the Supreme Court invalidated the death penalty as it is currently imposed, ${ }^{61}$ Justices Mar-

55. Id. at 417.

56. Id. Significantly, the 1961 Texas study documents that white attitudes toward crime in the black community are similar to those found nearly a quarter of a century before in a study of the disposition of murder indictments classified according to offender-victim racial groups in six southern counties from 1930 to 1939. Johnson, The Negro and Crime, in The Soctology of Crime and Delinquency 419 (M. Wolfgang, L. Savitz \& N. Johnson eds. 1962). Gunnar Myrdal also considered this phenomenon:

As long as only Negroes are concerned and no whites are disturbed, great leniency will be shown in unost (criminal) cases. This is particularly true in minor cases which are often treated in a humorous or disdainful manner. The sentences for even major crimes are ordinarily reduced when the victim is another Negro.

1 G. MYrdal, AN American Dilemma 551 (1944).

57. DETRO1T Court STUDX, supra note 33, at 26, 36.

58. Id. at 34. The report adds that "low-status" black defendants (as revealed by dress) are even more likely to receive a jail sentence. Furthermore, even black dcfendants who wear middle-class attire are three times less likely to get a fine only scntence than whites dressed the same way. Id.

59. Id. at 16-18.

60. PRESDENT'S CRIME COMMISSION RePORT, supra note 29, at 143.

61. Furman v. Georgia, 408 U.S. 238 (1972). 
shall and Douglas noted that they were particularly disturbed by the death penalty's discriminatory impact on minorities. ${ }^{62}$ But even as late as several years ago, the courts continued to affirm sentences of death for blacks convicted of raping white women, despite statistical evidence and judicial notice of a clear racial component in such sentences. ${ }^{63}$ Even the periodic necessity of reversing-on other grounds - some of the most shockimg of these convictions, seemed to provide no judicial lesson of the strength of the societal pressures that operate in these prosecutions. ${ }^{64}$

\section{Studies Disputing the Existence of Racial Bias in the Courts}

Some studies question the accuracy of research attributing disparities in arrest and sentence statistics to racial discrimination. They suggest instead that variation in statistics is a function of differences

62. Justice Marshall cited the National Prison Statistics which show that of 3,859 persons executed since $1930,1,751$ were white while 2,066 were black. Furman v. Georgia, 408 U.S. 238, 364. In Texas, from 1927 to 1968, according to a study cited by Justice Douglas, in several capital cases where blacks and whites were codefendants and thus received separate trials, the white was sentenced to life imprisonment or a term of years, and the Negro was given the death penalty. In rape cases, blacks were far more likely than whites to receive the death penalty. $1 d$. at $250 \mathrm{n.15}$. In Virgimia, 41 men have bcen executed for rape since 1908, 13 for attempted rape, and robbery. All were black. Partington, The Incidence of the Death Penalty for Rape in Virginia, 22 WASH. \& LEE. L. Rev. 43 (1965). In New Jersey, where the black population had grown from 3.5 percent im 1910 to 8.15 percent im 1960 , a study revealed that 74 of the 232 persons sentenced to death since 1907 (32 percent) were non-white. The author of the study found no justification for a presumption of racial prejudice from these figures, but conceded that such a presumption might arise from data indicating that "whereas eight times as many non-whites have been executed as commuted, only four times as many whites have been executed as commuted." Bedau, Death Sentences in New Jersey 1907-1960, 19 Rutgers L. Rev. 1, 18-19 (1964).

63. Statistics prepared by the U.S. Bureau of Prisons for the years 1930-62 show that of 446 persons executed for rape in the United States, 399 were black, 45 were white, and 2 were of other races. Maxwell v. Bishop, 398 F.2d 138, 144 (8th Cir. 1968). Professor Marvin Wolfgang studied rape convictions in 12 southern states (where virtually all of the states that authorized the death penalty for rape are located). Based on his findings he testified: (1) that the critical variables were race of the offender, race of his victim, and sentence; (2) compared to other rape defendants, Negroes convicted of raping white victims were disproportionately sentenced to death; and (3) "no variable of which analysis was possible could account for the observed frequency." Id. at 143. The Maxwell court refused, however, to find petitioner's sentence in violation of the 8th amendment's cruel and unusual punishment provision, stating that it "is simply not prepared to convict Arkansas juries of unconstitutional racial discrimination in rape cases." Id. at 145.

64. See, e.g., the "Scottsboro Boys" cases, Powell v. Alabama, 287 U.S. 45 (1932); Norris v. Alabama, 294 U.S. 587 (1935); and Giles v. Maryland, 386 U.S. 66 (1967); U.S. ex rel. Mongomery v. Ragen, 86 F. Supp. 382 (N.D. Ill. 1949). Generally such convictions are reversed on procedural grounds, most frequently jury discrimination. While some states may try to enact statutes designed to preserve the death penalty in certain murder cases, it is expected that the Supreine Court's invalidation of the death penalty because of its arbitrary application [Furman v. Georgia, 408 U.S. 238 (1972)] will finally terminate the imposition of this punishment for rape. 
in patterns of criminal behavior. Edward Green, a leading spokesman for this position, concludes from an analysis of 1,437 sentences in a Philadelphia criminal court that societal prejudice and the resulting caste status of blacks greatly affects the nature of crimimal behavior and the legal character of interracial crime as contrasted with intraracial crime. ${ }^{65}$ Segregation, according to Green, limits the access of blacks to "culturally patterned norms of deviant behavior as well as conventional behavior." As blacks are assimilated into what Green calls "the white middle class culture value system," not only will their criminal rate decline, but the crime pattern for blacks and the punishinent imposed will increasingly approximate the white pattern. ${ }^{06}$

Not only will many blacks disagree with Green's contention that racial discrimination does not contribute to higher arrest rates and longer sentences for blacks, they would suggest that the argument is meaningless. If, as Green acknowledges, it is racism that has prevented the assimilation of blacks into the "white middle class culture value systein," then the asserted even-handed treatment for blacks loses significance for all but the inost theoretical social scientists. Certainly the poor black defendant caught in the criminal justice system can be excused if he fails to note any significance in whether society or the court is responsible for the differential treatment he receives. ${ }^{07}$

Another, more intensive study, conducted by the Stanford Law Review, also minimizes the importance of race in the criminal courts, concluding that race plays no role in explaining the incidence of the death penalty in Califorma. ${ }^{68}$ This study examined first degree mur-

65. Green, Inter- and Intra-Racial Crime Relative to Sentencing, in RACE, Crime, AND JUSTICE, supra note 30, at 284. According to Green:

The offenses of Negroes who transgress against members of their own race are relatively high in impulsiveness and low in the elements of repetitiveness and malicious intent. Hence they are the least severely punished. The greater strictness of the penalties awarded in $\mathrm{N}-\mathrm{W}$ cases compared with $\mathrm{W}-\mathrm{W}$ cases for assaultive offenses, including robbery, is due to the fact that the crimes of the $\mathrm{N}-\mathrm{W}$ are of a more aggravated nature, indicating a deeper internalization of the value of violence.

Id. at 297.

66. Id. Similar conclusions were reached in a study of 662 homicides that occurred in Cleveland, Ohio, between 1947 and 1954, which found a very high correlation between socio-economic conditions and incidence of homicide. R. BENSING \& $O$. SCHROEDER, HOMICIDE IN AN URBAN COMMUNITY (1960).

67. In another study of a small northern industrial city with large numbers of black and white migrants from rural settings, Green found that "among groupings of persons more or less homogeneous with respect to occupation and nativity there is no consistent trend of racial difference in arrest rates." Green, Race, Social Status and Criminal Arrest, in RACE, CRIME, AND JUSTICE, supra note 30, at 103 . Such conclusions may be useful to refute those who still subscribe to the genetic explanation for high black crime rates, and may be accurate in the area where the data was gathered, but it is too sinall a sample to undermine the many studies that have found racial discrimination in the courts.

68. Note, A Study of the California Penalty Jury in First-Degree-Murder Cases, 21 Stan. L. Rev. 1297, 1307, 1421 (1969). 
der penalty decisions by California juries between 1958 and 1966 in an attempt to determine their fairness. A total of 238 cases were subjected to statistical analysis. Questionaires covering 178 possible elements of each case were formulated to elicit information on the characteristics and background of the defendant and his victim, the circumstances of the crime, the conduct of the trial, and the judges and attorneys involved. The authors used the questiounaire to collect data from state files and also sent it to every judge, prosecutor, and defense attorney involved. The analysis concluded that:

the juries in the cases under study defimitely followed a system of standards, a large percentage of which are "rational;" there was no significant racial bias, but there was a strong economic bias; and a number of aspects about the conduct of the trials had an undesirable impact on the penalty decisions of the juries. ${ }^{69}$

Yet, as Professor Harry Kalven noted in his preface to this study, the quality and force of the analysis can be criticized on at least two levels. First, the choice of who should die among those the legislature had made eligible for death, often depended "on factors of the greatest subtlety, nuances of personality and demeanor. These are precisely the kinds of facts that might well escape the net of the after-thefact questionnaire."70 Secondly, Kalven suggests, the analysis may involve a "spurious correlation" stemming from the inability to "control for the interaction of other factors with the factor being tested." short, such a retrospective analysis is only an approximation of the original experiment. ${ }^{22}$

Both Dr. Green and the Stanford study concluded that economic bias, not racial discrimination, explains the differential treatment. Since race and socio-economic status interact in such a complex of ways, the claim that poverty but not race is the operative factor is, in

69. Id. at 1307.

70. Id. at 1300. A dramatic illustration of the limitations of the questionnaire can be seen in a study of federal jury trials based on intensive interviews with 225 jurors in a northern area between January 1954 and June 1955, which found that many persons bring their personal prejudices to the jury box. One juror reported: "Niggers have to be taught to behave. I felt that if he hadn't done that, he'd done something else probably even worse and that he should be put out of the way for a good long while." Broeder, The Negro in Court, in RACE, CRIME AND Justice, supra note 30, at 303.

Prof. Kalven co-edited a famous jury study which examined how juries viewed crime in a subculture. The inaterials were too sketchy to permit conclusions, but several cases are mentioned indicating the tendency of juries and judges to hold blacks to a less strict standard of conduct where the victim is also black. H. Kalven \& H. ZeISEL, THE AMERICAN JURY 339-44 (1966). In a typical explanation for the jury's action, a judge explained: "If this had been a white man he would have been convicted. Negroes in cases of this type receive more than equal rights; juries seem to think it's okey for thein to cut, if its another colored person that is cut." Id. at 341 .

71. Note, supra note 68 , at 1300 .

72. Id. at 1300 . 
effect, not to say much of any significance when it is recognized that those who are poor are so often non-white. The Stanford authors comment that "[o]nce the effects of other aspects of the case were removed, the defendant's or victim's race had no effect on the penalty variable." "73 Yet it is the artificiality of such a separation of elements that is most vulnerable to attack. The impact of the racial variable cannot be isolated so easily from the wealth variable.

Further, Jerome Skolnick's comments on the racial bias of policemen $^{74}$ can serve as a useful analogy for criticizimg much of the methodology employed in this study. As Skolnick notes, police in the routine performance of their duties use all the usual derisive terms referrimg to blacks but believe that the term "racial bias" does not accurately describe their attitudes.

To say of somebody that he is biased against another is to make an accusation rather than a descriptive report of feelings. The policeman knows what it means to hate or fear or merely dislike. But he finds it difficult to accept a term which transforms an explicit emotion-hatred-into a fuzzy and condemnatory abstraction. ${ }^{75}$

Similarly here, the fimding of no racial bias may simply be due to the unpopularity of admitting overt racism. The judges and lawyers to whom the questionnaires were sent may have denied their own prejudice or the prejudice of the juries involved simply because of their aversion to the term "racial bias." This realization further reinforces Kalven's point that subtle nuances may have dramatically affected the results of this study.

The studies cited here are representative rather than exhaustive. Nevertheless they seem to substantiate the claim widely presented in criminology literature that, at every level, criminal courts in this country practice racial discrimination. It is the recognition of these practices that leads black defendants to conclude that the system is stacked agamst them and that since justice is unattainable, they had best seek the best deal they can. This goal is hardly made more attainable by disrupting the court-a reason that alone explains why disruptions by black defendants are rare.

\section{III}

\section{Criminal Law Procedures-A Cause of Black Apathy}

It is little comfort to the black defendant that much of the unfairness blacks experience is attributable to deficiencies inherent in the

73. Id. at 1421 .

74. J. Skolnick, Justice Without Trial 80-83 (1966).

75. Id. at $81-82$. 
court system. Neither does it alter his perceptions about his chances for justice. To the black defendant the courts are part of an alien process controlled by a white majority that created it and that could, if it chose, eliminate the deficiencies. Regrettably, the much discussed revolution in criminal procedure has changed the actual plight of the average criminal defendant so little that black defendants have not been given reason to alter their conception of the criminal justice system. It is not that the crininal procedure decisions were unwelcome. Rather, it is that many of them were intended less as innovations than as means of requiring police and prosecutors to comply with long established rules of due process. ${ }^{76}$ The effect of these decisions even in that regard, however, may be unsubstantial. For example, Miranda, ${ }^{77}$ one of the most controversial of the decisions, has had only slight impact on law enforcement. As one empirical report found, "The police continue to question suspects, and succeed despite the new constraints." The interrogation situation was found to be "inherently coercive," and the required warnings, even when given, fail to place the suspect on an equal footing with the police. ${ }^{78}$ Academics debate the value of the judicially-imposed reforms, but those who spend much time in our criminal courts will likely agree with Professor Tigar that the procedural protections have made thein "neither palladiums of liberty nor citadels of justice. ${ }^{\prime 79}$

The criminal courts can be condemned for faults that range far beyond the overcrowded docket theme so favored by judges in speeches to bar associations. There is, for example, the serious and far from uncommon occurrence in which a criminal conviction is obtained by

76. E.g., Miranda v. Arizona, 384 U.S. 436 (1966).

77. Id.

78. Seeburger \& Wettick, The Miranda Decision: Effects on Confessions and Convictions, 29 U. PITT. L. REv. 1 (1967); Note, Interrogations in New Haven: The Impact of Miranda, 76 YALE L.J. 1519, 1613 (1967). The hysterical opposition to Miranda by the "law and order" forces has not been diminished by the data indicating that the Miranda protection has not decreased the abihty of law enforcement agencies to apprehend suspects and obtain convictions. But the Supreme Court, its new postWarren conservative majority apparently caught up in the current surge of pro-law enforcement fervor, has seriously undermined the Miranda protection and, in the process, raised questions about the candor and integrity of its decision-making process. See Dershowitz \& Ely, Harris v. New York: Some Anxious Observations on the Candor and Logic of the Emerging Nixon Majority, 80 Y ALE L.J. 1198 (1971). Cf. Lego v. Twomey, 404 U.S 477 (1972) (the prosecution need prove by only a preponderance of the evidence that a confession was voluntarily given).

79. Tigar, Foreword: Waiver of Constitutional Rights: Disquiet in the Citadel, 84 HaRv. L. Rev. 1, 7 (1970). Blacks exposed to those courts and their procedures will certainly have reason to agree with Michael Tigar's observation that:

Unfortunately, the constitutional revolution in criminal procedure has amounted to little more than an ornament, or golden cupola, built upon the roof of a structure found rotting and infested, assuring the gentlefolk who only pass by without entering that all is well inside. 
the perjury of police witnesses. ${ }^{80}$ Since Mapp v. Ohio, ${ }^{81}$ it has become standard procedure in some police departinents for an arresting officer to testify that, as he approached, the defendant dropped the evidence to the ground; the officer picked it up, found that it was contraband, and placed the defendant under arrest. The defendant denies this story, usually contending that the police simply walked up and searched him. One judge has noted that the extraordimary number of cases in which such testimony has been given suggests a disturbing amount of police perjury. ${ }^{82}$

Faced with police witnesses both willing and able to lie, defendant's counsel often decides his client must do the same. One young New York lawyer, a veteran of several years of civil rights litigation in the South, was shocked when he began a criminal practice to find how common police lying was. He fimally decided that when his clients requested trial, they should "find" at least two witnesses who would support their stories. ${ }^{83}$

The well known defense counsel Martin Garbus asserts that police perjury is widespread and is used not only to get convictions in

80. Comment, Police Perjury in Narcotic "Dropsy" Cases: A New Credibility Gap, 60 GEO. L.J. 507 (1971). See also Rosengart, The BuST Book for LAWYers, 66-67 (1970).

81. 367 U.S. 643 (1961).

82. In a case with these facts [People v. McMurty, 69 Misc. 2d 63, 314 N.Y.S.2d 194 (N.Y. City Crim. Ct. 1970)], New York Supreme Court Judge Irving Younger wrote:

Were this the first time a policeman had testified that a defendant dropped a packet of drugs to the ground, the matter would be unremarkable. The extraordinary thing is that each year in our criminal courts policemen give such testimony in hundreds, perhaps thousands, of cases-and that, in a nutshell, is the problem of "dropsy" testimony. It disturbs me now, and it disturbed me when I was at the Bar. Younger, The Perjury Routine, The NAtion, May 8, 1967, at 596:

"The difficulty arises when one stands back from the particular case and looks at a series of cases. It then becomes apparent that policemen are committing perjury at least in some of them, and perhaps in nearly all of them."

Id. at $64-65,314$ N.Y.S.2d at 195-96. Finding the testimony on eaeh side balanced, and noting that state law placed the burden of proof on defendant, the judge reluctantly denied the motion to suppress.

83. The view in the black community that the judicial process is racist is so pervasive that black defendants experience great difficulty convincing witnesses to testify. The fear that testimony against police may result in reprisals, combined with the feeling that testimony for the black defendant will prove futile, makes it almost impossible to convince even eyewitnesses to testify in a police brutality case. W. STrinofellow, My People is the ENEMy 57-59 (1964).

In Kinney v. Lenon, 425 F.2d 209 (9th Cir. 1970), the court, in ordering the release from a juvenile detention home of a black youth to assist in the search of witnesses for his trial, took notice of the difficulty lawyers often have in overcoming the apathy and reluctance of potential witnesses: "It would require blindness to social reality not to understand that these difficulties may be exacerbated by the barriers of age and race." $l d$. at 210 . 
"dropsy" and "plain view" cases, ${ }^{84}$ but also to cover up police brutality, bribery, and shakedowns. Garbus maintains that "among all the lawyers that $\mathrm{I}$ know-whether they are into defense work or prosecutionnot one of them will argue that systematic police perjury does not exist. We may differ on its extent, its impact; we may differ on solutions, but no trial lawyer that I know will argue that police perjury is nonexistent or sporadic." $\$ 85$

Thus, even the presence of witnesses-whether or not they tell the truth-may not suffice to prevent a conviction in today's criminal courts. The Boston Court Study reported that in a closely contested case

[t]he defense presented a number of witnesses to counter the sole prosecution evidence, the testimony of the arresting officer. The judge resolved the case by declaring: "Well, I don't know who to believe. Just to be safe I'll find you guilty." The defendant, given a suspended sentence and a short period of probation, did not assert his right to a new trial. ${ }^{86}$

This steady de facto erosion of the standard that a defendant's guilt must be sustained by proof beyond a reasonable doubt is another serious problem in the criminal courts. The Boston study found "strong indications that the government's burden is reduced to showing that the preponderance of the evidence points to the defendant's guilt." ${ }^{87}$ Sheila Rush, former director of the Community Law Offices in New York, agrees with this finding, suggesting that a major reason for the reduced standard is the concern of judges and juries with the high urban crime rate. They are willing to rely on police testimony because failing to do so would represent a lack of faith and support for what they see as the main defense against crime. ${ }^{88}$

The casual observer might well conclude that competent counsel would protect criminal defendants against police witnesses who lie, and burdens of proof that shift. And this does sometimes happen. ${ }^{89}$ But

84. In plain view cases the officer testifies that the defendant's apartment door was open and seeing the narcotics in "plain view" on a table or sofa, he went inwithout a warraut or probable cause-and made the arrest.

85. Cohen, Police Perjury: An Interview With Martin Garbus, 8 CRIM. L. BulL. 363, 367 (1972). See also F. GRAhAM, The SelF-INFLICTEd Wound 136-37 (1970).

86. Boston Court Study, supra note 39, at 83. Of course, every aspect of the structure of our criminal courts militates against judicial objectivity and uniformity. See Smith \& Blumberg, The Problem of Objectivity in Judicial DecisionMaking, 46 SOCIAL ForCES 96 (1967).

87. Boston Court Studx, supra note 39, at 82-83.

88. Lecture by Sheila Rush, Harvard Law School, Oct. 23, 1970. The Boston Court Study [supra note 39, at 83] also found that a major reasou for the reduction in the burden of proof was the "greater inherent credibility given the testimony of police officers."

89. ROSENGART, supra note 80 , at 67-70. 
all too often, the right to counsel guarantee of Gideon $v$. Wainwright $t^{00}$ provides legal representation that is of little value to the defendant and, in some instances, wrose than no representation at all. ${ }^{11}$ Gideon and its offspring too often give poor defendants nothing more than a brief encounter with a lawyer whose most rigorous activity in the courthouse is "standing around and calculating how many cases at $\$ 50$ per case is a healthy day's work," defender so deluged with cases that he cannot do even a minimal job of representation in any of them. Most black defendants need far better legal counsel than that if they are to stand half a chance in the criminal justice system.

The Detroit Court Study showed that while the presence of an attorney tended to reduce the number of guilty pleas for both black and white defendants, the assistance of an attorney for the white defendants was three times as helpful in preventing a guilty plea as was the presence of an attorney on behalf of the black defendants. ${ }^{03}$ If anything, the conditions are worse in Boston's lower courts, where poor defendants with assigned counsel not only receive fewer continuances, have higher bail set, and are found guilty more often than defendants with private counsel, but defendants with assigned counsel often fare little differently, and soinetimes worse, than defendants who have no lawyer at all. ${ }^{04}$

With the number of lawyers willing to represent criminal defendants already far short of the need, courts have been quite reluctant to reverse convictions on grounds that defendant did not receive "effective assistance" of counsel. ${ }^{95}$ In keeping with this reluctance, the St-

90. 372 U.S. 335 (1963).

91. Defendants are now entitled to counsel at trial for any offense that could result in imprisonment. Argersinger v. Hamlin, 407 U.S. 25 (1972), and at "every critical stage" of the prosecution. See, e.g., Coleman v. Alabama, 399 U.S. 1 (1970). However, a defendant has no right to counsel during an identification held at the police station after he is arrested but before he is indicted or formally charged. Kirby v. Illinois, 406 U.S. 682 (1972). During the 1971 term the Court also held that conviction by less than unanimous verdicts in noncapital cases did not violate defendant's 14th amendment rights. Johnson v. Louisiana, 406 U.S. 356, (1972); Apodaca v. Oregon, 406 U.S. 404, (1972). The use of six-man juries in criminal cases had been approved in Williams v. Florida, 399 U.S. 78 (1970).

92. Tigar, supra note 22, at 5 . Attorneys of this stripe have been observed in the "bullpens" where lower court defendants often await trial, "demanding from a potential client the loose change in his pockets or the watch on his wrist as a condition of representing him." PRESIDENT's CRIME COMMISSION REPORT, supra note 29, at 129.

93. Detroit CouRT STUDY, supra note 33, at 17-18.

94. Boston COURT STUDY, supra note 39, at 32-34.

95. In one court's view, defense counsel is only one of several officers of the court who have the responsibility of insuring the defendant receives a fair trial. Thus defense counsel's mistakes, "although indicative of lack of skill or even incompetency, will not vitiate the trial unless on the whole the representation is of such low caliber as to 
preme Court during the same term in which it moved so vigorously to protect the sanctity of the courtroom against disruptions, ${ }^{96}$ decided Chambers $v$. Maroney. ${ }^{97}$ There, the Court refused to disturb the conviction of a defendant claiming that his legal aid attorney, whom he met for the first time en route to the courtroom a few minutes before his second trial, made so belated an appearance that he could not have furnished effective legal assistance. The Court, in denying the habeas corpus petition, stated that not only was reversal of every conviction following tardy appointment of counsel not required, but a petition alleging only belated appointment accompanied by allegations of incompetence or inexperience, need not always be given an evidentiary hearing. ${ }^{98}$

Although a decision like Chambers affects all criminal defendants who must rely on appointed counsel, its burden falls most heavily on the black defendant. These problems of quality of counsel, burden of proof, and perjured pohice testimony, when added to the similar injustices existing in bail, plea bargaining, sentencing, probation, and parole procedures, leave hittle doubt of the basis for black apathy on the question of fair trial.

\section{IV.}

\section{The Effect of Racism on Black People}

\section{A. The Rise and Fall of Overt Racism in the Law}

Even those who concede that racial and economic injustice exists in the courts usually point to the improvement in court conditions and the judicially mandated progress toward elimination of government sanctioned racial bias. Such statements are not maccurate, but like the changes wrought by the series of constitutional protections engrafted onto crimimal procedure during the last decade, the improvements are more heart-warming to those who worked to attain them than helpful to those they were designed to shield.

amount to no representation and to reduce the trial to a farce." United States ex rel. Feeley v. Ragen, 166 F.2d 976 (7th Cir. 1948) quoted in People v. Washington, 41 Ill. $2 d$ 16, 241 N.E.2d 425 (1968).

96. Illinois v. Allen, 397 U.S. 337 (1970).

97. 399 U.S. 42 (1970).

98. Id. at 54. Everyone concedes that public defenders are too burdened with cases to provide most defendants with much more than an experienced voice in the guilty-plea negotiations. But since the Constitution guarantees those charged with crime a trial, and not just an admmistrative proceeding, it would seem only a matter of time before someone documents how little counsel and representation most indigent defendants recieve, and, using that data, obtains an imjunction barring the public defender from the courts until funds required for an adequate level of representation are provided. 
American courts began their history burdened with the responsibility of enforcing slavery laws. ${ }^{99}$ The Constitution compromised the issue of black rights to ensure white unity, ${ }^{100}$ and the Supreme Court's early decisions in the racial area reflected both the law's and society's firm belief that blacks were not entitled to rights reserved for white men. ${ }^{101}$ Even those blacks who were not slaves had little status in the early courts. With some few exceptions, generally when whites were willing to espouse their cause, ${ }^{102}$ blacks fared badly both in northern and southern courts. ${ }^{103}$ There were exceptions, but Chief Justice Taney, ostensibly summarizing English and European law of the century before the Constitution, may also have summarized American judical opinion to 1857 when lie wrote that blacks "had no rights which the white man was bound to respect." 104

The intertwinement of racism and economic self-interest that led to the approval of a national Constitution focusing on the protection of individual rights of white men, yet condoning the slavery of blacks, did not disappear with the end of the Civil War. The amendments enacted to correct the original omission of blacks served mainly to nurture the growth of industry. ${ }^{105}$ Their promise for blacks was emasculated by a Supreme Court all too ready to further the country's efforts to heal the division thought (erroneously) to have been caused by the race question. Thus, blacks were isolated in a status, admittedly better than slavery, but considerably less than the equality automatically granted to even the least of white men.

Appropriately, it was the Supreme Court that named the status "separate but equal,"106 and it survived, despite continuing efforts to expose its injustice and hypocrisy, until Brown v. Board of Education was decided in 1954. ${ }^{107}$ But a continuing concern for majority imterests was displayed the following year in the "all deliberate speed"

99. K. Stampp, The Peculiar Institution 192-236 (1956).

100. Lynd, Slavery and the Founding Fathers, BLACK HISTORX 117-31 (M. Drimmer ed. 1968).

101. Roper, In Quest of Judicial Objectivity: The Marshall Court and the Legitimation of Slavery, 21 Stan. L. REv. 532 (1969).

102. See, e.g., Commonwealth v. Aves, 35 Mass. (18 Pick.) 193 (1836); Jackson v. Bulloch, 12 Conn. 38 (1837) (slaves brought by their masters into jurisdictions where slavery abolished held to be emancipated); United States v. Amistad, 40 U.S. (15 Pet.) 518 (1841) (blacks taken from Africa who revolted and captured a Spanish ship transporting them from one Cuban port to another were free native Africans rather than slaves).

103. L. LITWACK, NORTH OF SLAVERY 64-112 (1961).

104. Dred Scott v. Sandford, 60 U.S. 393, 407 (1857).

105. See, e.g., Slaughterhouse Cases, 83 U.S. (16 Wall.) 36 (1873); Allgeyer v. Louisiana, 165 U.S. 578 (1897); Lochner v. New York, 198 U.S. 45 (1905).

106. Plessy v. Ferguson, 163 U.S. 537 (1896).

107. 347 U.S. 483 (1954). 
standard for eliminating school segregation. ${ }^{108}$ This doctrine delayed integration for a decade and inay have eliminated altogether the best opportunity for fully integrating the public schools. ${ }^{109}$

Although it did not eliminate public school segregation, Brown did provide the legal leverage that led to the elimination of odious segregation laws and practices in a nyriad of public institutions, including the courts. ${ }^{110}$ Rigid segregation of courtrooins was found to violate the equal protection clause in Johnson $v$. Virginia, ${ }^{111}$ and in Hamilton v. Alabama, ${ }^{112}$ the Court set a minimal standard of courtesy for black litigants by overturning a contempt citation issued when a black woman refused to testify because the judge insisted on calling her by her first name.

\section{B. The Continuing Presence of Institutional Racism}

But a Court finally willing to find a constitutional basis for barring degrading segregated seating and racial insults, has experienced more difficulty with the fundamental, if nore subtle, prerequisites of justice. Participation of blacks on jury panels is an example. The post-Civil War Supreme Court, generally hostile to blacks, had little difficulty holding that a black defendant charged with a crime was entitled to be tried by a jury from which members of his race had not been systematically excluded. ${ }^{113}$ Most recently, the Court reversed a black defendant's conviction because the grand jury selection procedure was not racially neutral and the statistically small number of blacks selected made out a prima facie case of racial discrimination that the state failed to rebut.114 Although these are helpful rules for the blatant case, they are hardly adequate to guarantee black defendants a trial by a jury of their peers. The Court has not expressly condoned evasion, but its decisions leave little doubt that, even in areas where eligible blacks are present in substantial numbers, it is possible to maintam blacks on jury lists in only token numbers, and, in some cases, to exclude thein from the jury altogether.

The systematic elimination of potential black jurors through use of the peremptory challenge is one way this may be done. The in-

108. Brown v. Board of Education, 349 U.S. 294 (1955).

109. Justice Black conceded that the phrase "turned out to be only a soft euphemism for delay." Alexander v. Holmes County Bd. of Educ., 396 U.S. 1218, 1219 (1969).

110. See cases cited in 2 T. Emerson, D. Haber \& N. Dorsen, Political and Civil Rights IN THE UNITED States, 1794-1824 (3d ed. 1967).

111. 373 U.S. 61 (1963).

112. 376 U.S. 650 (1964), rev'g per curiam 275 Ala. 574, 156 So.2d 926 (1963).

113. Strauder v. West Virginia, 100 U.S. 303 (1879). Subsequent decisions are summarized in Swain v. Alabama, 380 U.S. 202 (1965).

114. Alexander v. Louisiana 405 U.S. 625 (1972). 
sensitivity with which the Court in Swain v. Alabama ${ }^{115}$ rejected an effort to limit this practice, therefore, dealt a heavy blow to those seeking to broaden the right of a fair jury to a substantive standard available to all black defendants. After Swain, the right to a fair jury is inerely a well sounding statement of use only to those few black defendants fortunate enough to have coinpetent counsel. ${ }^{116}$

Furthermore, the history of the judicial system as a tool for rectifying other social and legal wrongs has also given blacks little reason to expect justice. The courts have been quite hesitant, for example, to find constitutional protection for persons prosecuted because of alleged interracial sexual conduct. It took the Supreme Court an inordinately long time to overrule an early case $\mathrm{e}^{117}$ and reach the obvious decision, first that state statutes providing higher penalties for interracial fornication contravened fundamental individual rights ${ }^{118}$ and later that antimiscegenation statutes, contrary to an earlier ruling of the Court upholding their validity, were indeed inconsistent with the Constitution as well as a moral abomination. ${ }^{119}$

There is no denying that during the post-World War II period, blacks experienced a renaissance of hope for racial equality. Much of this hope was based on the courts. Out of this judicial crusade came a parade of precedent-making cases that did change the status of black Americans for the better. All blacks could vicariously share the victory of those who, through court action, were enabled to ride on a train without eating in the "jim crow" car, ${ }^{120}$ buy a home from a willing white seller without regard to a restrictive covenant, ${ }^{121}$ join the NAACP without fear of public exposure and persecution by the state, ${ }^{122}$ and protest peacefully a private restaurant's refusal to serve them on a nonsegregated basis. ${ }^{123}$

But all too frequently, availing oneself of this judicially-enabled progress required levels of economic well-being beyond the reach of most blacks. And even those who sought to take advantage of gains

115. 380 U.S. 202 (1965).

116. See, Kuhn, Jury Discrimination: The Next Phase, 41 S. CAL. L. REv. 235

(1968). See also Note, The Case for Black Juries, 79 YALE L.J. 531 (1970).

117. Pace v. Alabama, 106 U.S. 583 (1883).

118. McLaughlin v. Florida, 379 U.S. 184 (1964).

119. Loving v. Virginia, 388 U.S. 1 (1967).

120. Henderson v. United States, 339 U.S. 816 (1950); Morgan v. Virginia, 328 U.S. 373 (1946); Mitchell v. United States, 313 U.S. 80 (1941).

121. Shelley v. Kraemer, 334 U.S. 1 (1948).

122. Bates v. Little Rock, 361 U.S. 516 (1960); NAACP v. Alabama, 357 U.S. 449 (1958).

123. Bell v. Maryland, 378 U.S. 226 (1964); Robinson v. Florida, 378 U.S. 153 (1964); Lombard v. Louisiana, 373 U.S. 267 (1963); Peterson v. City of Greenville, 373 U.S. 244 (1963). 
found that somehow the doctrine of stare decisis did not work for racial discrimination cases, and to enjoy the benefits of even widelyheralded Supreme Court decisions required more litigation. Those blacks who sought to follow the pioneers found that they too had to become pioneers, with all the exertions, expense, harassment, and danger that pioneering in America's racial frontier has always mvolved.

This lesson came painfully to middle-class blacks who had felt that the white establishment would sympathetically and readily respond to racial injustice without the necessity of disruptive prodding. The masses of black poor, however, were spared the disillusionment of the "black bourgeoisie." Their daily lives provided little proof that the highlypublicized decisions of the Brown era heralded a racial reformation through law. Radicial black youth increasingly spoke of achieving change through violent revolution. Much of this talk was rhetoric, but there were those who believed. Some were willing to act on their beliefs, thereby posing increasingly for the courts a danger far more serious than anything Illinois $v$. Allen, ${ }^{124}$ or more stringent bar sanctions, could cure. Condemnation and criminal prosecution of blacks who embrace violence does not alter the soundness of the position that blacks continue to be exploited and oppressed in this country because of race. Nor can one deny that the courts offer only an unpredictable forum for those seeking legal remedies for even basic injustices. All too often the judicial process condones or even reinforces the racism endemic in American society. In sum, there is still little reason for blacks to trust the judicial system.

\section{V.}

\section{THE EFFECT OF RACISM ON BLACK LAW STUDENTS AND LAWYERS}

It is hardly likely that those in positions of power in our courts will pay much heed to the condemnations of black revolutionaries. But charges of racisin in the courts do not coine from militants only. Blacks at every level of the legal process-law students, lawyers, and judges-concur with the conclusions, if not the rhetoric, of the militants. Opinions differ as to whether any particular black defendant can or cannot get a fair trial. There is agreement, however, that racism, whether overt or institutional, leaves the availability of a fair trial highly problematical.

\section{A. The Black Law Student}

It probably comes as no surprise that contemporary black law students, products of the black pride-black power era, are so convinced that the legal system is corrupted by racism that even the opportunity

124. 397 U.S. 337 (1970). 
to attend America's premier law schools in unprecedented numbers ${ }^{125}$ has creatcd serious emotional ambivalence. ${ }^{126}$ Fear of co-optation by the system becomes inore important than the traditional student fear of flunking out, and as graduation approaches the mental anguish is not over which large law firm to join, but whether joining any large law firm, even for a few years, will not constitute a "sell out" and a rejection of the community the student had sworn to return to and serve. $^{127}$

But decisions as to how best to serve the black community are more controversial to black law students than the issue of black defendants receiving a fair trial. In January 1971, the author sent a questionnaire to each of the approximately 100 black students at the Harvard Law School seeking their opinions on the impact of racism on American law. The 44 who responded felt that racism does lessen the chance that black defendants in criminal cases will receive a fair trial. ${ }^{128}$ Generally, the students felt that whatever chance for a fair trial exists is substantially reduced if the black defendant is charged either with a violent crime against a white victim, ${ }^{129}$ or a crime growing out of militant or revolutionary activity. ${ }^{130}$

Significantly, despite their views on the fair trial issue, only two black students would consider resorting to radical tactics on a regular basis, even at a trial of a black militant. Twenty-eight students indicated their willingness to advise or permit "non-traditional courtroom

125. As a result of recruitment programs in many of the nations law schools, there may now be as many blacks learning the law as practicing it. Accurate data is not available, but estimates indicate that in 1968 there were about 4,000 black law school graduates, of which number 3,000 were working in the profession. Gellhorn, The Law Schools and the Negro, 1968 Duke L.J. 1069, 1073 n.22 (1968). During the 1969-70 school year, therc were 2,110 black students attending 133 law schools. Hall, Statistical Analysis of the LSAT-AALS-CLEO Survey of Minority Group Students in Legal Education, 1970 TolEDo L. REv. 983, 984 Table 1. During the 1971-72 school year, according to a 1971 Survey of Minority-Group Students in Legal Education, gathered by the American Association of Law Schools, there were 5,568 minority group students in American law schools, including 3,732 blacks.

126. See McPherson, The Black Law Student, Atrantic, Apr. 1970, at 93.

127. See Bell, Black Students in White Law Schools: The Ordeal and the Opportunity, 1970 TOLEDO L. REv. 539.

128. The sampling is not a large one, but Harvard's reputation and pioneering in the recruitment of black students have enabled the school to attract an impressive black student body from all sections of the country. The students hold a wide varicty of political views. These factors suggest that the opinions expressed are representative of black law students around the country.

129. "Do . . . chances of a fair trial change if the black defendant is charged with a violent crime against a white victim?" "No change": 5; "chances are lesscned somewhat": 4; "chances are substantially reduced": 33 .

130. "Do such chances of a fair trial change if the black defendant is charged with crime growing out of militant or revolutionary activity?" "No change": 4; "chances are lessened somewhat": 6; "chances are substantially reduced": 35. 
behavior" in special situations as a means of exposing racist judicial practices, but 19 students expressed the view that they would never use such tactics. ${ }^{131}$

A further indication that the students were uncertain how to cope effectively with racism in the courtrooin came in response to a question concerning suggested modifications in jury selection procedures that would ensure that blacks were placed on juries in proportion to the percentage of blacks in the area where the alleged crime was committed. Most students were uncertain whether such a procedure would affect racism in criminal cases, although a substantial number felt it would be helpful. ${ }^{132}$

Nor do the students feel that law school effectively prepares black students to meet the special burdens of representing fellow blacks. Only two students felt the law school was providing them with adequate preparation to represent black defendants in trials affected by racist practices. A dozen students felt that preparation im this area was inadequate, while 28 students felt the problem was ignored coinpletely. ${ }^{133}$

Based on the results of the survey of Harvard's black law students, it seems likely that some of the next generation of black lawyers will at least consider unorthodox courtroom behavior on behalf of clients whoin they perceive as victinus of racism. But the opinions that individuals express while students are not necessarily the views they will hold after graduation. Many black law students who begin their legal training certain that they will return to the ghetto later accept an offer with a large white firm, concluding that the opportunities for growth in the profession and perhaps service to the black community are greater there. Similarly, many students now willing to consider courtroom protests may opt for a inore traditional form of representation when the time for decision comes.

131. The question read: "In representing black clients (particularly black militants) would you advise or permit 'non-traditional courtroom behavior' including demonstrations, outbursts, etc. as a means of neutralizing or exposing racist judicial practices?"

Howard Moore, militant, black counsel to Angela Davis, does not share the students' ambivalence regarding the value of disruptive trials. In advance of her trial, he explained how he would represent Miss Davis. "We do not intend the trial should be a spectacle or a circus. . . . We will not be a source of public disorder and disruption in the court. . . W We see no need to be abusive to court officials." The Times (London), Apr. 19, 1971, at 4, col. 5.

132. Seventeen students felt proportional representation of blacks on criminal juries would be helpful; two students thought it would not help; and 24 were uncertain.

133. The question read: "To the extent you see black persons (criminal defendants or not) likely to receive trials affected by racist practices and beliefs, how do you rate the preparation the law school provides to assist you in combatting this problem?" 


\section{B. The Black Lawyer}

Certainly, those with militant ideas will have black models-both historical ${ }^{134}$ and contemporary ${ }^{135}$-after which to fashion their behavior. But a black law student entering the legal profession is more likely to be concerned with erasing the less than impressive image stamped on most black lawyers of the past. Until the last decade or so, excepting a few outstanding men, most of whom had built their reputations in the civil rights field, ${ }^{136}$ black lawyers were struggling practitioners. Besides having to contend with courthouse racism, ${ }^{137}$ their legal educations were inadequate, and their job opportunities were limited, their

134. Robert Morris, one of the country's first black lawyers [who assisted Charles Sumner in the unsuccessful effort to desegregate Boston's public schools, Roberts v. City of Boston, 59 Mass. 198 (1850)] is reported to have participated in the eventual freeing of Shadrack, an escaped slave who was originally remanded back to slavery after a decision under the Fugitive Slave Act of 1850, J. Daniezs, IN Frerdom's BirTHPLACE, A STUdy of Boston Negroes 61-62 (Johnson Reprint ed. 1968).

135. In its first issne, the Black Law Journal, a publication by black students at the UCLA Law School, hailed 31-year-old Kenneth V. Cockrel of Detroit as one of the outstauding black members of the legal profession. Significantly, the students were particularly impressed with his inilitant courtroom tactics.

Mr. Cockrel, who is known for his fiery oratory, has recently set a most valuable precedent in his role as advocate for the people. After having attempted to present the case of one of his clients before a local Recorder's Court judge, he was held in conteinpt by the judge for alleged remarks made immediately after the hearing. At that time he described the judge as a racist pirate, thief, and other allegedly derogatory comments. Mr. Cockrel had been airing his feelings with regard to what he considered illegal and racist activity on the part of the judge. At his contempt proceedings he was exonerated by pleading truth as defense. Although currently facing possible disciplinary action from the bar association, it is not expected that any formal action will be taken. In any case, he has broken the tradition that a lawyer must stand idly by while his client is being railroaded into jail.

1 BLACK L.J. 41 (1971).

136. Federal District Judge Robert L. Carter, former NAACP general counsel, and an outstanding civil rights lawyer, has written:

[W] hile black lawyers spearheaded the developinent of constitutional doctrine favorable to the Negroes' cause, and their success raised the status of the Negro lawyer, only an infinitesimal percentage of the Negro bar actively participated in the development of civil rights law.

Carter, The Black Lawyer, THe Humanist, Sept.-Oct. 1969, at 12-13.

137. All black practitioners recognized the burdens under wheh they were required to function. A little-noted civil rights case [See Dawley v. City of Norfolk, Va., $159 \mathrm{~F}$. Supp. 642 (E.D. Va. 1958), aff'd per curiam, 260 F.2d 647 (4th Cir.), cert. denied, 359 U.S. 935 (1958)] records the futile efforts of two black attorneys to gain judicial recognition of their plight. Relying on the Supreme Court's decision in Brown v. Board of Education, the attorneys asked a federal district judge to enjoin the maintenance of segregated restrooins in the Norfolk County Courthouse. The petition argued that they had to secure their hivelihood from the general public, and that the presence of the racial signs on the restroom doors conveyed the impression to the public that judges consider Negro attorneys inferior. This, in turn, adversely affected the prestige of Negro attorneys in the public eye, thereby diminishing their earning capacity as black lawyers. The district judge rejected this argument and dismissed the case, finding the matter under the control of the state court, and expressing doubt that Brown was applicable to restroom facilities. 
practices consisting of cases brought by clients too poor to hire white lawyers. It was generally beheved that white lawyers could do more for black clients than could black lawyers, a belief that, whatever its initial accuracy, soon became self-fulfilling as black practitioners lost clients sorely needed for both professional development and respectable economic survival.

Even more damaging to the black lawyer was the knowledge that, despite his best efforts, racism could at any time tip the scales against him and his client. It is inpossible to measure how destructive this knowledge was to the selfconfidence, motivation, and finally to the coinpetence of black attorneys. But it may be assumed that this realization generally served to suppress rather than spark any tendency the lawyer might have to disrupt a courtroom on behalf of his client. Indeed, many black lawyers were commonly seen as court jesters whose courtroom behavior was more likely to evoke humor than a contenpt citation. ${ }^{138}$

Some black lawyers did fit this stereotype. Many who did used comic appearance and behavior as an important defense mechanism to enable them to serve black clients without upsetting white court officials. At least one black lawyer in Mississippi who long before the civil rights invasion traveled the state representing blacks, including those charged with rape and other violent crimes against whites, probably survived only because his appearance and demeanor did not threaten whites.

But the reality of ultimate powerlessness is always in the background. In one case, this lawyer represented a black charged with raping a white woinan in a sinall Delta town. At the end of a day of pretrial proceedings, the judge called in the black lawyer and suggested that simce it was Friday he might be well advised to return to his home in Jackson rather than spend the weekend in the small town. The lawyer took the advice, and later learned that his client had been dragged from the jail by a mob late that might and lynched.

Sometimes the debilitating knowledge of powerlessness comes to the black lawyer im less dramatic but no less discouraging experiences. An exaniple requires recalling a personal and still painful experience

138. A black law student has written bitterly of the offensive image of the Negro lawyer, Algonquin J. Calhoun, as portrayed in the Amos and Andy series. But while critical of the program's characterization of Calhoun as a happy bumbler who had picked up a handful of legal terms which he applied freely and frequently to any and all situations, the student notes:

... [I]t is impossible to deny that the Calhoun image did in fact reflect an important, if unpleasant, truth about the American legal system for it did accurately symbolize the status that most black lawyers were held in the eyes of their white colleagues.

Cochran, Some Thoughts on American Law Schools, the Legal Profession, and the Role of Students, 1970 TOLEDo L. REv, 623-25. 
in the early 1960's, when as a NAACP Legal Defense Fund lawyer, I served as plaintiffs' counsel in dozens of school segregation cases. I shall never forget one hearing in a Deep South school case in which the trial judge had subjected my young clients and their attorney to the worst kind of harassinent, ridicule, and invective. More than 10 years after the Supreme Court's decision in Brown we were still trying to. enjoin the local school board from continuing to operate completely segregated public schools, and the court was reacting to my arguments as though they were radical, unique, and abhorrent. Finally following a period of the closest possible cross-examination of a 12-year-old black girl as to why she thought she could do acceptable work in a white school, a recess was called. During the recess the judge administered the oath of citizenship to a sinall group of woinen who had apparently married servicemen overseas. The same judge who had treated my chents so rudely was all courtesy and consideration during the brief cereinony. He bade the women not to be nervous and welcomed thein to their new citizenship status in terms so generous in praise and patriotism as to bring a tear to the eye and a tug to the heart of all but the most hardened cynic.

That day, in that place, the term "hardened cynic" accurately described my feelings. It was all too obvious, to me at least, that in those few brief moments those white women were received into this society to a degree that neither my clients nor myself would likely ever equal. The white woinen were presumed worthy by the standard that counted: they were white.

When the school case resumed, I neither disturbed the court with a violent outburst nor made any mention of the paradoxical scene I had just witnessed. The situation for iny clients, I rationalized, was already bad enough. Why make it worse by a gesture that would bring then further grief? And yet such incidents are damaging to pride, unsettling to confidence, and insidiously destructive of manhood. Imagine the impact on the practitioner who encounters such traumatic experiences every day.

Conditions for black lawyers have improved greatly in the last few years, but racial discrimination is far from ended for either the black lawyer or his client, a fact painfully apparent not only to the lawyers themselves, ${ }^{139}$ but to black judges as well. ${ }^{140}$ The problems pre-

139. In the fall of 1968, a group of black lawyers met at Capahosic, Virginia, and formed the National Conference of Black Lawyers (NCBL). In its Declaration of Concern and Commitment, the lawyers stated:

There is no existing institution of the legal profession as presently constituted available to address itself to the problem of white racism as it affects substantial justice for the Black Americans of this country.

The group pledged itself to "the development of unique and unorthodox legal remedies to insure the effective implementation of the just demands of Black people for le- 
sented by state bar examinations illustrate the difficulties that remain. For years, blacks have felt that bar exams were used to limit the number of blacks admitted to practice. Now in Pennsylvania, these charges have been proven, ${ }^{141}$ and investigations or lawsuits charging racial bias in bar exams have been initiated in several other states. ${ }^{142}$ Thus even though there may now be as many blacks learning the law as practicing it, due to law school recruiting programs, ${ }^{143}$ racial obstacles continue to plague blacks even after they receive their law degrees.

gal, economic and social security and protection. . . ." All of this action would be necessary the group found because:

The systematic suppression of Black people continues notwithstanding the plethora of court decisions, civil rights laws, anti-poverty legislation, human relations commissions, enlarged political representation and the other symbolic promises to Blacks which serve as this society's substitute for true equality.

[Copies of the complete statement are available on request from the NCBL office.]

140. The black lawyer's racial problems are not forgotten by those few blacks who become judges. Edward F. Bell, Judge of the Wayne County Circuit Court in Detroit, and past President of the National Bar Association (the black bar group) said recently that:

[A]nybody today who thinks that the black man has finally achieved parity and is receiving justice in the courts of our nation is sadly mistaken. ... Having been black lawyers, and black practitioners, we know that our courts have, in fact, failed the poor aud have failed the black people. . . .

Bell, The Black Lawyer and the Judiciary, Harvard L. School BULL., Feb. 1971, at 31-32.

Another black judge, George Crockett (Detroit Recorder's Court), who practiced in the civil riglits and civil liberties fields and who was severely criticized for ordering the release of more than 100 blacks held in the aftermatl of the Detroit New Bethel Baptist Church shootings in 1969, reviewed the incident and concluded:

Racism breaks down our vaunted boasts of 'equality before the law' at each and every step of the judicial process. From the time the suspect is seized and arrested, through the period of his detention, the issuance of a warrant, the pre-trial examination, and the trial itself, his color and/or his pocketbook too often determine his fate.

Crockett, A Black Judge Speaks 53 Judicature, Apr.-May 1970, at 360-61.

141. Pennsylvania's Exam: A Study in Black and White, JURIs DocTor, Mar. 1971, at 5. A special five man committee appointed by the Philadelphia Bar Association found that only racial bias could account for the grossly disproportionate percentage of blacks who fail each examination. Data indicated that whites had a two out of three chance of passing the exain, while blacks had a one in four chance. The committee charged that the State Board of Examiners, in deciding whether borderline applicants should pass or fail, made use of personal data to discriminate against blacks. Bar officials denied the charges, but altered the structure of the Board of Bar Examiners and changed the bar exam.

142. The states include California, Delaware, Florida, Georgia, Indiana, Louisiana, Maryland, Michigan, and New Jersey. Report of Dean Robert McKay, New York University Law School, to an AALS Conference on Minority Law School Problems, New Orleans, La., Apr. 23, 1971 . On November 9, 1972, the California Supreme Court denied a petition filed by Public Advocates, Inc., a San Francisco public interest law firm, on belialf of black and Chicano law graduates seeking a judicial declaration that the California bar exam is discriminatory in effect and not job-related. Espinoza v. Committee of Bar Examiners, No. S.F. 22928 (filed June 20, 1972). Statistics iu the petition indicate that Anglos have an eleven times better clance of passing the exam than minorities.

143. See note 125 supra. 
For all the reasons set forth in this Article, black practitioners, whether militant or not, daily face the prospect of having to respond courteously to judges, some of whom combine in seemingly unlimited measure, qualities of arrogance, ignorance and bigotry. Demeaning comments must be ignored, and objectivity is abandoned in hearings in which the outcome seens clearly predetermined. Trials in such courtrooms, and every black lawyer knows such courtrooms are far from exceptional, are the very antithesis of the "palladiums of hiberty" and "citadels of justice" referred to by the Court in Illinois v. Allen. ${ }^{144}$

It is a significant testament to either the faith they place in the system or the conviction that protest will be unavailing, that so few black lawyers have succumbed to the strong temptation to respond to these judges in kind and to refuse to cooperate with a system of justice that is a farce for so many blacks. Chief Justice Burger has repeatedly urged civility on the part of lawyers in the courtroom, ${ }^{145}$ but it may be that his comments have only served to hinder efforts by black lawyers to attain equality in the courts for themselves and their chents. For there are judges and court officials who will interpret the Chief Justice's remarks as justification for unleashing their already strong inclination to harass black lawyers and black clients into conforming with personal definitions of "civility."

It should now be clear that civility of lawyers was not the most pressing problem facing American courts in the beginning of this decade; it was probably closer to being least important. While the spotlight was focused on lawyer conduct, a far more important problem, racism in the courts, was consigned to the shadows where it remains today.

\section{CONCLUSION}

At every stratum of the systen-chent, law student, lawyer, and judge-the black man is aware of racism in the administration of criminal justice. Though not as blatant as in the past, its effects remain sufficiently obvious to vitiate the continuing debate over whether a black inan can receive a fair trial.

What every black knows about racism and the courts is not a mere manifestation of group paranoia. So many studies support this perception with data that even those who intuitively felt that the national boast of justice for all was premature are sometimes shocked. But these findings come as no surprise to black people, who still regard the judicial system as no more likely to respond affirmatively to their racial grievances than any other institution in the society.

144. 397 U.S. $337,346-47$ (1970). See United States v. Dellinger, 41 U.S.L.W. 2283 (7th Cir. Nov. 21, 1972), criticizing the demeanor of Judge Julius Hoffman in the Chicago Seven trial.

145. See, e.g., N.Y. Times, May 19, 1971, at 28, col. 1. 
In the wake of the Chicago Seven trial, the leaders of the American bar evidenced immediate concern about disruptions in the courtroom. Black lawyers and black clients, despite the provocation of racism and imjustice, have been so beaten by the system that they contribute little to whatever cause exists for this concern. While the Chief Justice pleads for "civility," blacks continue to seek justice in the courts. Their search cannot be fruitful, except in token instances, unless the attention now focused on the rare cases of courtroom disruption is shifted to the all too prevalent problem of racism in the judicial system.

It is tempting to conclude this piece on a positive note by calling for a concerted effort to rid the criminal justice system of racism in all its forms. Painful experience has taught, however, that verbal attacks on racism, particularly racism in the criminal law process, are futile when directed to law and order types. What is worse, these arguments are worse than useless when directed to concerned liberals who, recognizimg that they can do nothing about so mammoth a problem, read the data, accept the conclusions, decry the imjustices, and thereby obtain an mtellectual cartharsis that is the virtual antithesis of the kind of determined action out of which change must come.

It is for this reason that so often the problem of racism in the courts becomes submerged beneath more generalized social issues, and reform efforts become directed at generalized mequities in the systen. Even when a long-ignored problem surfaces with a riot, protest, or exposé in the media, and emergency action is called for, the resultant crash programs are usually nothing more than "avoidance mechanisins" that only once again remove the problem froin consciousness. ${ }^{146}$ Avoidance mechanisins or inere structural and procedural reforms that fail to attack the root issue of racism in the courts will not solve the problem. ${ }^{147}$

If any institution is equipped to attack racism, it would seein to be the courts. They are generally viewed as the repository of the national ideal of justice; ${ }^{\mathbf{1 4 8}}$ their work is momitored by the adversary

146. See P. Slater, Pursuit of Loneliness: American Culture at the Breaking Point 14-15 (1970).

147. Commenting on a Criminal Justice plan prepared for New York City, Judge Robert L. Carter complained that the plan's major weakness was its emphasis on procedural reforms and its failure to confront squarely the issue of racism in the crimmal courts. Metropolitan Information Service, New York City Almanac, Apr. 1971, at 9. It should be added, somewhat paradoxically, that the role of race in the problem of social neglect in this country may add to the difficulty of achieving reform, especially in the criminal law, if the public fears that blacks will be the chief beneficiaries. See Heilbroner, The Roots of Social Neglect in the United States, in Is Law Dead 288, 296 '(E. Rostow ed. 1971), suggesting that the United States lags so far behind other nations in all social reform, iucluding housing, welfare, health, and prisons, largely because the beneficiaries of reform would be disproportionately Negro.

148. See Green, supra note 65, at 296-97. 
system; and procedural safeguards and appellate processes stand ready to check abuses. When faced with a serious racial problem that cannot easily be avoided, however, the courts, like society, tend to seek a solution that guarantees maximum protection to vested majority interests and provides only that protection to the black victims necessary to substitute calm for disruption.

Moreover, the judicial preference for deciding issues on procedural rather than substantive grounds has permitted courts, whether intentionally or not, to endorse the democratic ideal while leaving all but the most odious practices virtually imtact. ${ }^{140}$ The right to a jury from which blacks have not been systematically excluded, for example, is almost meaningless without limitations on the prosecution's peremptory challenges. Yet in Swain v. Alabama ${ }^{150}$ the Court upheld an unlimited prosecutorial privilege by solely considering the procedural issues and ignoring the substantive effect. According to those who have studied the impact of racism on jurors, even a different result in Swain would not have begun to provide black defendants with the ideal: a jury of their peers. And no legislative or judicial reform now on the horizon suggests any possibility of improvement.

To fear that reforms directed at extirpating racism in the system will lead to courtroom disruptions is imconsistent with the character of black defendants. The majority of black defendants are members of a class that has borne the brunt of a combined burden of poverty and racism. They manifest not only the adverse effects of economic deprivation and racial bias, but the devaluation of self ${ }^{151}$ that is the consequence of life at the bottom of a society that still believes blacks are less than human. ${ }^{152}$ By any definition they are an oppressed group,

149. For a discussion of substantive vs. procedural activism as applied to the death penalty cases, see Goldberg \& Dershowitz, Declaring the Death Penalty Unconstitutional, 83 HARV. L. REV. 1773, 1798-1802 (1970).

150. 380 U.S. 202 (1965).

151. Joel Kovel describes in detail the psychiatric aspects of society's exploitation of blacks to fulfill emotional as well as economic needs:

The accuunulation of negative images forced upon blacks in America amounted to presenting them with one massive and destrunctive choice: either to hate one's self, as culture so systematically demanded, or to have no self at all, to be nothing. With the passage of time and abstraction, these alternatives ainounted to the same thing. . . .

J. KOVEL, WhIte RACISM: A PSYchohItory 196 (1970). See also W. Grier \& P. COBBS, BLACK RAGE (1968). Indeed, most blacks are as subject to feelings of self-hate and the concomitant anti-social manifestations of that self-hate as were the Jcws in the Nazi concentration camps who reacted to their group suppression in ways painfully familiar to the black experience in America-both during slavery and today. See S. ElKINS, SLAVERY 103-15 (1959) for a comparison of Jews in concentration camps with blacks in American slavery.

152. Only the Black Muslims seem capable of reaching this group. See generally C. Lincoln, The Black Muslims in America (1961); E. Essien-Udom, Black 
and outbursts of rage directed at anything but themselves will be rare. ${ }^{153}$ And while blacks are constantly admonished to lift themselves, serious efforts to accomplish this are often viewed with the greatest suspicion by white society. Groups like the Black Muslims are looked upon as enemies of society. Their extraordinary work in the prisons is suppressed, and their organization harassed ${ }^{154}$ just as the now acceptable civil rights groups were a few years ago when they sought to desegregate public facilities, ${ }^{155}$ which is really a more subtle means of developing self-pride.

There is nuch in contemporary history that supports James Baldwin's assertion that "The American triumph-in which the American tragedy has always been implicit-was to nake Black people despise themselves."156 As long as there is any truth in Baldwin's statement, then the criminal justice system will do little more than carry out the sentence of those society has already condemned.

NATIONALISM (1962). By reiterating the lesson that whites are responsible for the condition of blacks, and should be hated not loved for their deeds, the Muslims have literally resurrected thousands of black people, providing them with pride, hope, and in a few fanous instances, the insight to disavow the limiting aspects of the sect's beliefs. See A. Haley, The Autobiography of Malcolm X (1964); E. Cleaver, Soul ON ICE (1968).

153. "The problem in connection with crime in the Negro is not to account for the fact that the rates are so high, but rather to account for the fact that they are not much higher, considering that the provocations, in the form of continuous frustration, are so much stronger and more frequent than in the white." A. KARDINER \& L. OveseY, The Mark of Oppression 342 (1961). See also L. SAvitz, Dilemmas in CrimiNOLOGY 61 (1970) for a suggestion that because of racial discrimination "[a] very strong argument could be made for constructing a theory of Negro delinquency and criminahty which would be quite different from any possible model of criminal behavior among the whites."

Developing a similar theme, sociologist Andrew Billingsley criticizes the comparative nature of much social science analysis of black people. He contends this approach requires an erropeous assumption that at some period in the past, blacks and whites lived as equals and received equal support and resources from the society. He calls for an analysis that recognizes the inequality that has always existed, predicting that this approach would necessarily focus on why so many, rather than so few, black children learn to read, stay out of jail, and manage to support their families. Billingsley, Foreward to Hill, The Strengths of BLACK Families XV (1971).

154. See, e.g., Weaver v. Pate, 390 F.2d 145 (7th Cir. 1968); Cooper v. Pate, 382 F.2d 518 (7th Cir. 1967); Walker v. Blackwell, 360 F.2d 66 (5th Cir. 1966); Richey v. Wilkens, 335 F.2d 1 (2d Cir. 1964); Sostre v. McGinnis, 334 F.2d 906 (2d Cir.), cert. denied, 379 U.S. 892 (1964); Sostre v. La Vallee, 319 F.2d 844 (2d Cir. 1963), cert. denied, 379 U.S. 950 (1964); Pierce v. La Vallee, 293 F.2d 233 (2d Cir. 1961).

155. See, e.g., NAACP v. Alabama, 377 U.S. 288 (1964); NAACP v. Button, 371 U.S. 415 (1963); Shelton v. Tucker, 364 U.S. 479 (1960); NAACP v. Overstreet, 221 Ga. 16, 142 S.E.2d 816 (1965), cert. denied, 384 U.S. 118 (1966).

156. Baldwin, An Open Letter to My Sister, Angela Y. Davis in IF THex Come IN THE MORNING 20 (A. Davis ed. 1971). 


\section{California Law Review}

\begin{tabular}{lll}
\hline Vol. 61 & JANUARY 1973 & No. 1 \\
\hline
\end{tabular}

\section{BOARD OF EDITORS}

\author{
Notes \& Comments \\ KEVIN F. KeLLY \\ WIILIAM F. CAPPS \\ Craig H. Casebeer \\ MARR S. DODSON \\ ANN FingaretTe Hasse \\ LESLIE ANN JOHNSON \\ Craig D. Miller \\ JOHN E. THORSON

\section{Projects} \\ JEFFREY M. ALLEN \\ Joseph P. DICtuccio
}

Susan Frelich Appleton

ALICE M. BEASLEY

MICHAEL J. BERTINETTII

Christopher C. Calkins

Raymond A. Diaz

PaUl E. Dorroh

KENNETH J. FISHBACH JR.

\author{
JAMES A. ASKEW \\ RANDALL IRA BARRAN \\ Willtam A. Cardwell, \\ Paul Clark \\ GARY JAY COHEN \\ Richaro Delgado \\ PhIIP R. Diamond \\ Patricia D. Douglass \\ JOHN A. GLOGER \\ RoBert A. GOODIN \\ DOUGLAS L. HAMMER \\ JAMES E. HARTLEY \\ ROBERT M. JENKINS III \\ MARTIN WAYNE JOHNSON \\ ELIOT S. JUBELIRER
}

\author{
Editor in Chief \\ STEPHEN L. KOSTKA \\ Managing Editor \\ STEPHEN JULIAN YODER \\ Managing \\ Gabrielle R. CAMpbell \\ JAMES DRUMMY \\ Peter Grossman
}

Associate Editors

ERNESTINE FoRREST

Howard W. Foss JR.

DAVID M. GLASS

DAVID GOLDBERG

Kelly Guest

JACK $H$. KAUFMAN JR.

LARY LAWRENCE

DANIEL J. LEER

Howard ALAN LATIN

ROBERT L. LAWRENCE

MICHAEL Robert LEVINE

MARY M. LOGALBO

PETER LOMHOFF

RANDALI R. MCCATtaREN

JULIE E. MCDONALD

ALAN MITTMan

Lise A. Pearlman

Larry PeItZman

JOSEPH P. POWERS

JAMES D. RICHMAN

GEORGE RUTHERGLEN

Administrative Assistant Patricta G. SMITH

\author{
Articles \& Book Reviews \\ IrA MARK ElLmaN \\ MICHAEL J. BAKER \\ Marsha Siegel BerzoN \\ DAVID F. BOYLE \\ Supreme Court \\ Palmer Brown Madden
}

Research

Steven S. BeLl

RICHARD KALISH

\section{Camille E. LeGrand}

Chardes H. Matthews, JR.

Raymond D. Pike

THOMAS E. RANKIN

Lee Charles Rosenthal

Craig M. Thomas

MARTIN J. THOMPSON

SUSAN SAWYER

CHRISTOPHER H. SCHROEDER

Thom Greenfield SentoN

HENRY SHIELDS, JR.

SCOTT SONNE

NANCX E. SULLIVAN

E. ElLZABETH SUMMERS

ANNE MCLeod Trebil Cock

Catalina Valencia

DAVID L. WAGNER

ULRICH WAONER

Patruck W. Walsh

ROBERT E. WIILETT

Thomas S. Williamson, JR.

Daniel D. Woo 